\title{
A Tertiary-Quaternary section at Sarsbukta, Spitsbergen, Svalbard, and its foraminifera
}

\author{
ROLF W. FEYLING-HANSSEN AND KAARE ULLEBERG
}

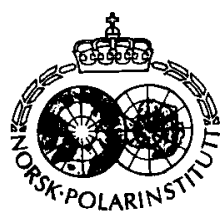

\begin{abstract}
Feyling-Hanssen, R. W. \& Ulleberg, K. 1984: A Tertiary-Quaternary section at Sarsbukta, Spitsbergen, Svalbard, and its foraminifera. Polar Research 2 n.s., 77-106.

Tertiary and Quaternary deposits outcrop in the coastal cliff of Balanusviken at Sarsbukta in VestSpitsbergen. The Tertiary deposits appear by their foraminifera to belong to the Middle to Upper Oligocene. The Quaternary deposits consist of an upper part of Late Pleistocene to Holocene age, and a lower part which had previously been considered Middle Weichselian of age. Its foraminiferal assemblages suggest a higher age (Late Saalian, Eemian?). This lower part of the Quaternary deposits is related to a series of raised beaches with an upper limit at $50 \mathrm{~m}$ above present day sea level. They were probably formed during the Eemian, and have not been distorted by later glaciation. The present study is based on sediment samples collected from the coastal cliff of Balanusviken, and particularly from that of Balanuspynten, Sarsbukta, Spitsbergen, during the summer expedition of Norsk Polarinstitutt in 1950.
\end{abstract}

Rolf W. Feyling-Hanssen, Department of Micropaleontology, Geological Institute, Aarhus University, DK-8000 C, Denmark; Kaare Ulleberg, Kløverstien 7, Ekebergfeltet, 3073 Galleberg, Norway.

\section{Introduction}

\section{Cliff and sediments}

The locality is situated on the east side of the northern part of the sound of Forlandssundet, Spitsbergen, at $78^{\circ} 40^{\prime} \mathrm{N}$ lat., $11^{\circ} 40^{\prime} \mathrm{E}$ long. (Figs. 1 and 2). The coastal cliff forms the small cove of Balanusviken between two projecting points, Balanuspynten to the southeast and Konglomeratodden to the northwest. It is located midway between the northern lateral moraine of the Aavatsmarkbreen glacier and the southern landlocked end of the Sarstangen spit (Figs. 3 and 4). The examined part of the cliff is approximately $1500 \mathrm{~m}$ long. Its height is nearly $25 \mathrm{~m}$ above sea level at Balanuspynten and approximately $11 \mathrm{~m}$ at Konglomeratodden. A generalized sketch of the cliff section is shown in Fig. 4. A sloping wave-built beach plain with curved and closely set beach ridges forms the land surface above the coastal cliff.

A detailed examination of the cliff (sampling and height measurements) was undertaken only at Balanuspynten and Konglomeratodden. The intervening cliff section has been sketched in from notes taken during a walk along the beach. Sample locations are marked with filled rings and numbers.

The lower $8 \mathrm{~m}$ of the section at Balanuspynten consists of a slightly consolidated micaceous clay.

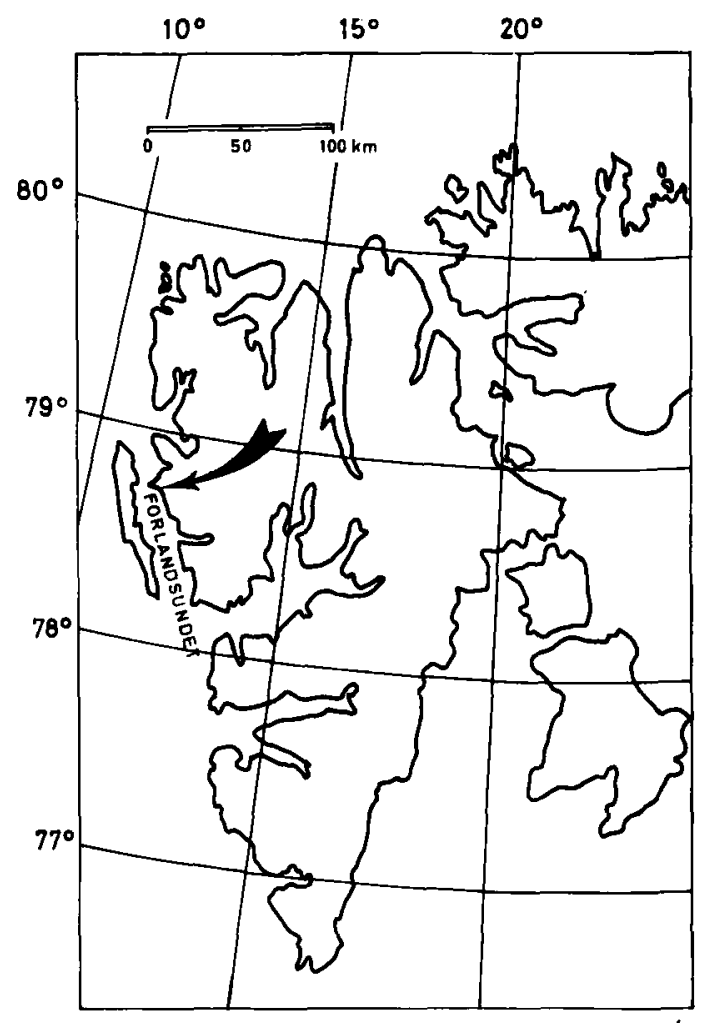

Fig. 1. Spitsbergen, showing the study area. 


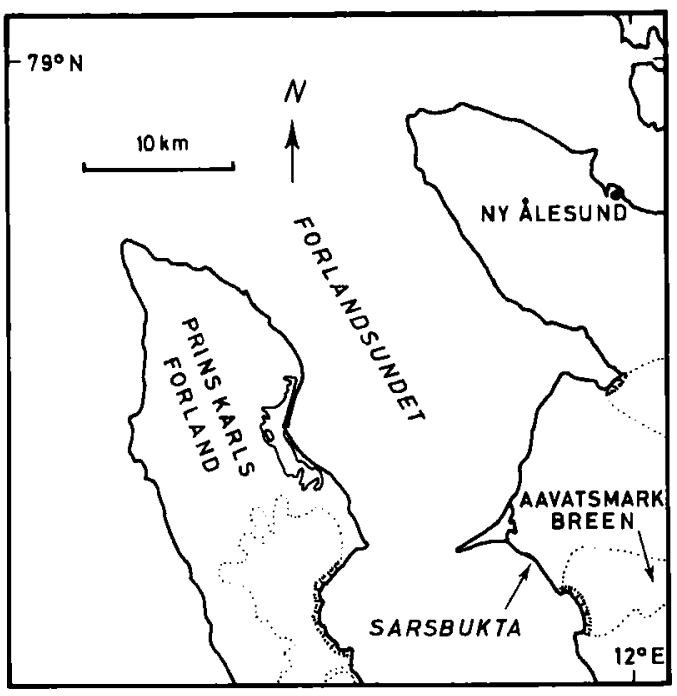

Fig. 2. Forlandsundet showing the investigated locality at Sarsbukta.
The surface of this clay rises gently towards the southeast, and disappears below sea level towards the northwest. This micaceous clay was not found at Konglomeratodden, but most presumably it occurs below sea level there.

A 1-2 cm thick layer of brown sandstone caps the micaceous clay at Balanuspynten. It seems to increase in thickness both towards the southeast and the northwest. Its strata dip at almost $26^{\circ}$ towards the northwest conforming with the surface of the micaceous clay. The sandstone disappears below sea level to the northwest of Balanuspynten but reappears near the base of the Konglomeratodden section, where it is at least $1 \mathrm{~m}$ thick and dips towards the southeast.

The sandstones are overlain first by finer and then coarser conglomerates. Their strata dip southeastwards in the northwestern part and northwestwards in the southeastern part of the cliff. They could probably represent filling of an

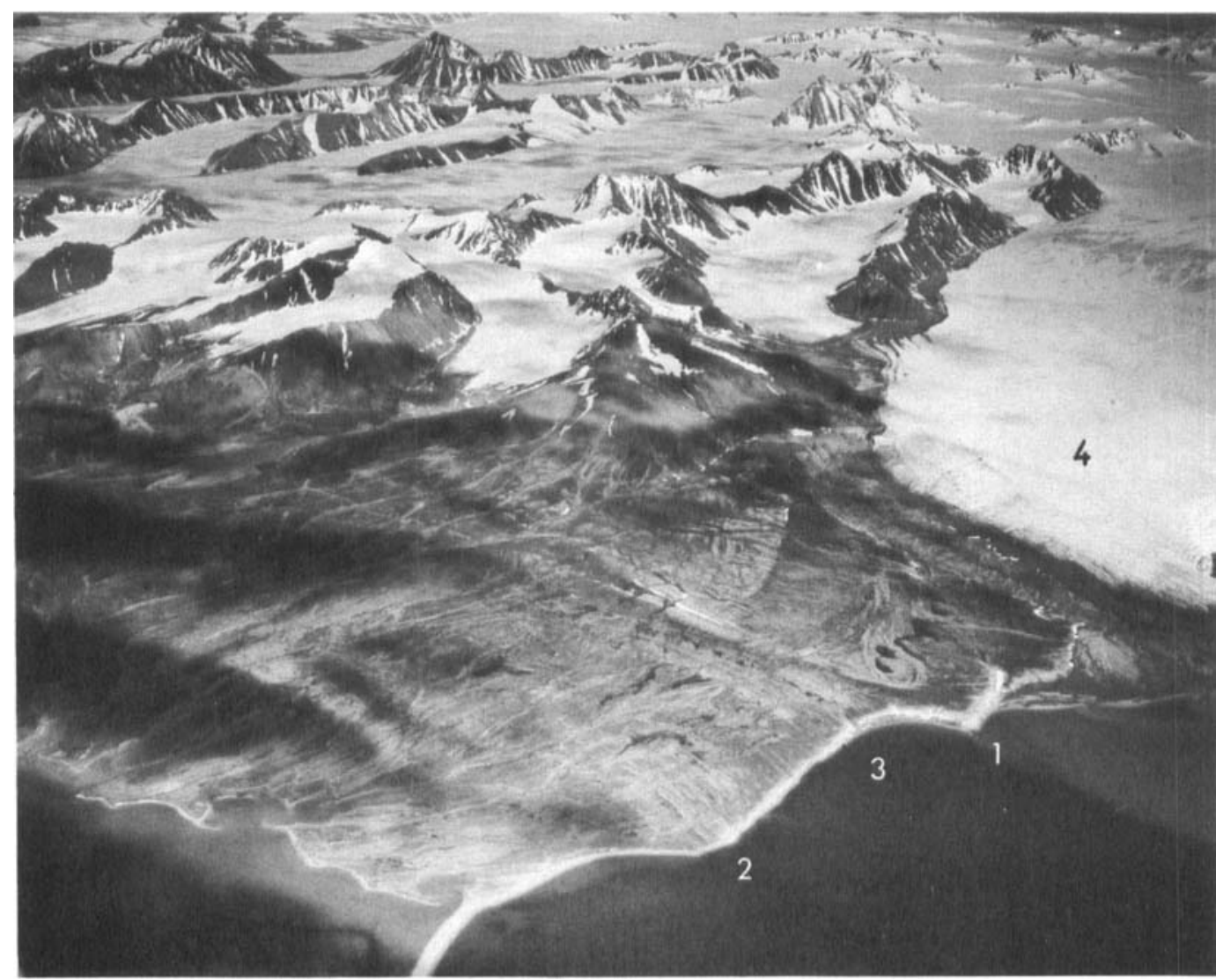

Fig. 3. The investigated localities: 1. Balanuspynten; 2. Konglomeratodden; 3. Balanusviken; 4. Aavatsmarkbreen glacier. Photo: B. Luncke, 1936. 
old river channel. The boulders are largely made up of gneisses, quartzites and crystalline schists of the Hecla Hook formation. They occasionally attain half a metre in diameter and give the deposit a till-like appearance. Occasionally lumps of a bluish plastic clay, perhaps of a weathered rock, were interspersed among the boulders. The boulder conglomerate is overlain by a finer stony clay which is in part soft and in part hard and consolidated.

These deposits wedge out towards the section at Balanuspynten (Fig. 4) but outcrop below Quaternary terrace deposits on the north side of the Recent northern lateral moraine of the Aavatsmarkbreen glacier.

A comparison of the rocks of Balanusviken with Holtedahl's (1913) observations on the east side of Forlandsundet and with the Sars Formation of Atkinson (1963) has not been attempted.

At Balanuspynten this Tertiary sedimentary sequence is interrupted by an unconformity at approximately $8 \mathrm{~m}$, above which unconsolidated layers of clay and sandy clay, silt, sand and gravel occur up to the terrace surface at nearly $25 \mathrm{~m}$ above sea level. Here these deposits dip $22^{\circ}$ towards the north-northwest. The sediments above $15.7 \mathrm{~m}$ above sea level were dominated by coarse sediments - sands and gravels. Microfossils were not expected from these deposits, and therefore only the lower half of the unconsolidated section was sampled. The highest sample (No. 259) was collected from a layer of silty clay at $15.3 \mathrm{~m}$ above sea level.

The unconsolidated part of the sequence is supposed to be of Quaternary age.

Valves and fragments of marine molluscs occur in these deposits: An assemblage characterized by the pelecypode genus Astarte together with small, short-valved Hiatella arctica (Linné), small Macoma calcarea and also some Arctica islandica (Linné) occurs in the lower part of the Quaternary, up to the coarse gravel at $13.2 \mathrm{~m}$ in the section of Balanuspynten, whereas large $M y a$ truncata Linné and large long-valved Hiatella arctica (Linné), typical of the pholadis form, dominate the upper part.

Astarte shells, mostly of Astarte crenata (Gray) from about $11 \mathrm{~m}$ above sea level at Balanuspynten (sample 255) was dated (Tauber, K3314) $>40,800$ B.P.

This lower part of the Quaternary did not occur in the section of Konglomeratodden, where sandy gravel with large Mya and Hiatella directly over- lies Tertiary deposits. Large Mya truncata and large and long-valved Hiatella arctica washed down in abundance in a gully immediately south of Konglomeratodden were collected and some of the Mya valves dated (sample 180850, Tauber K-3315) at 10,250 \pm 140 B.P. $(=8,300$ B.C. $)$.

This age is most probably representative of the Hiatella-Mya carrying the upper part of the Quaternary sequence at Balanuspynten as well. The great difference in age between the lower and upper parts of the Quaternary sequence suggests the occurrence of a second unconformity in the section of Balanuspynten, probably at the base of the $2 \mathrm{~m}$ thick gravel bed between 13 and $15 \mathrm{~m}$ above sea level (Figs. 4 and 5).

It is worth noting that there is no till, nor residual boulders of a till, in any part of the section. One might have expected that the Main Weichselian (Main Wisconsinan) ice sheet, which in other parts of the northern hemisphere had its maximal extension 18,000-20,000 years ago, would have left some trace in this section, being located so close to the present lateral moraine of the Aavatsmarkbreen glacier. Or could it be that the maximum extent of glaciation was not considerably greater during the Quaternary ice ages than it is today in an arctic area such as Spitsbergen? This thought was expressed by FeylingHanssen \& Olsson (1960), discussed and favoured by Feyling-Hanssen (1964c) and exhaustedly treated and partly favoured by Boulton (1979), Boulton et al. (1982), and Miller (1982). Most other authors dealing with the Quaternary glaciations of Svalbard favour an extensive ice, at least once during this period, covering not only Svalbard but also the Barents Sea (e.g. Salvigsen 1981; Salvigsen \& Nydal 1981; Salvigsen \& Österholm 1982).

Boulton (1979: 44, Fig. 10) indicates 'old moraine' to the north of the present northern lateral moraine of Aavatsmarkbreen. This may be a till older than the Weichselian or it may be a misinterpreted Tertiary conglomerate.

The locality described in the present paper is more or less the same as that mentioned by Livšic (1974: 13, Fig. 2, V-2-2, Table 2-outcrop of the Sesshøgda Formation on the east side of Forlandsundet) and described by Boulton (1979: 44, Fig. 10-raised marine Quaternary deposits).

\section{Material and methods}

Sediment samples were collected primarily from 


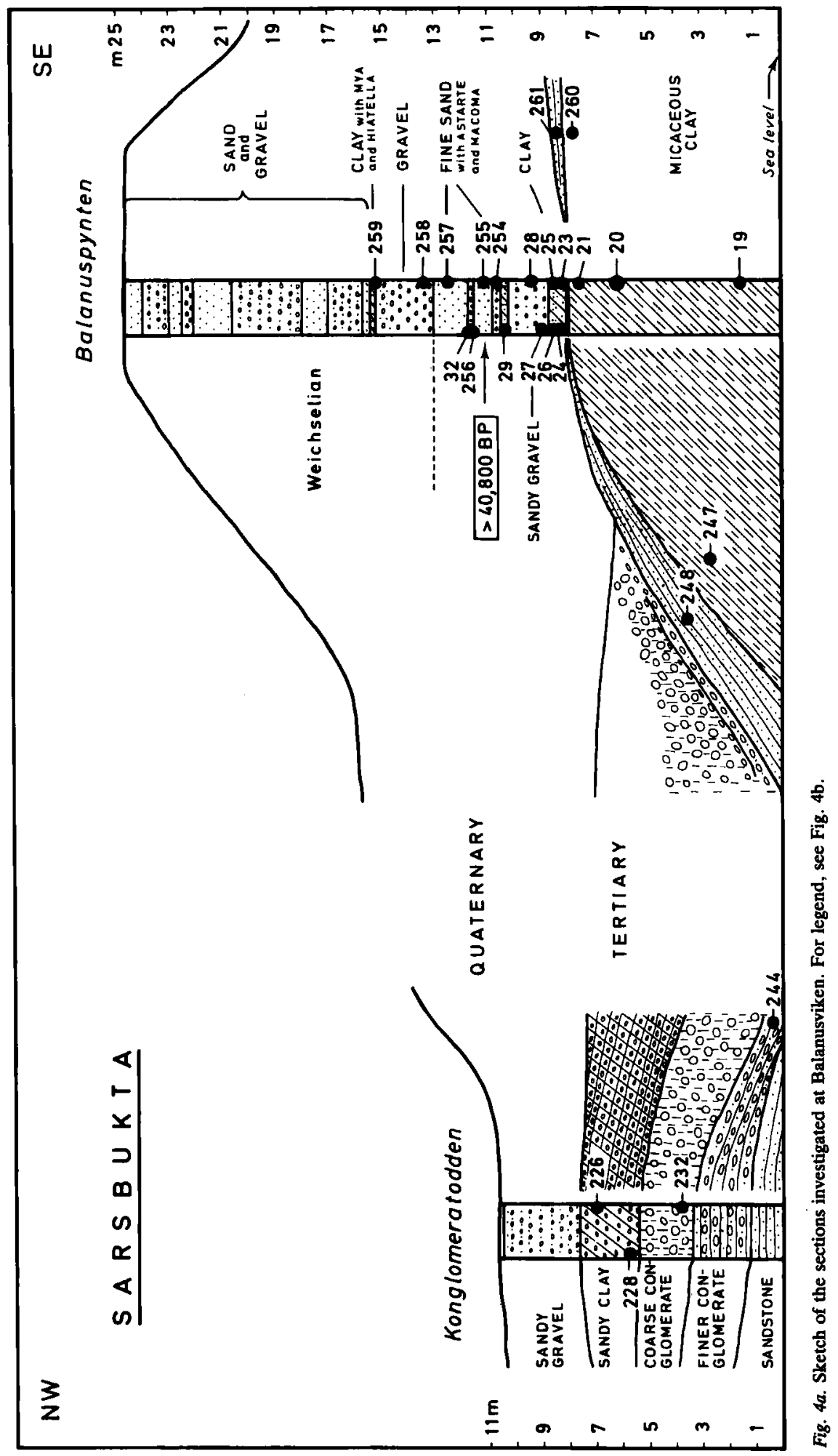




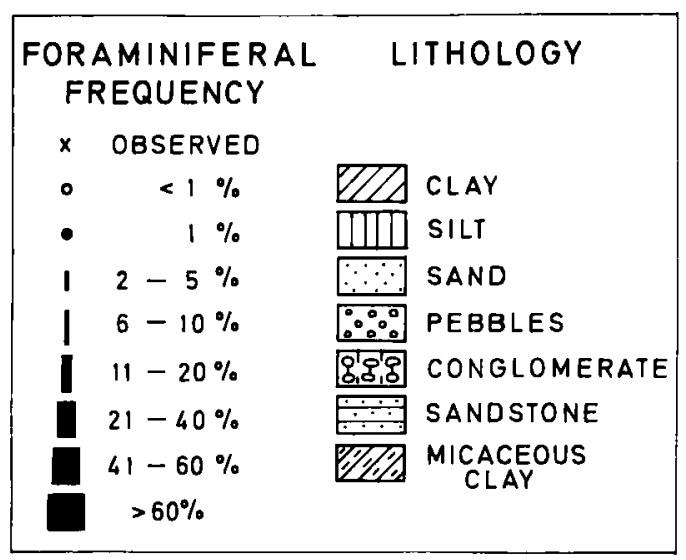

Fig. 4b. Symbols used in Figs. 4a and 5.

the finer-grained strata, as such sediments usually promise more microfossils than coarser-grained strata. Thus the upper part of the Quaternary sequence of Balanuspynten was left unsampled, whereas the lower part of the Quaternary was quite densely sampled (Figs. 4 and 5). Samples from the Tertiary are scattered. Samples 19 and 20 were collected from the section of Balanuspynten (Fig. 4), whereas the other Tertiary samples (indicated by circles in Fig. 5) have been inserted into the range chart in stratigraphical order (cf. Fig. 4 and Fig. 5). Samples 21, 226, 261 , and 232 were left out of the chart because they contained very few foraminifera.

The samples were processed in the standardized way (Feyling-Hanssen 1976; Feyling-Hanssen et al. 1971), and the results of the foraminiferal analyses are presented in the range chart in Fig. 5. Heights above sea level in metres are given on the left of the diagram. Next is indicated the appearing foraminiferal zonation termed $\mathrm{TA}, \mathrm{TB}$ (Tertiary A and B), QAL, QAU (Quaternary A lower and $A$ upper), QB and QC (the upper parts of the Quaternary of the section). Then follows a column with sample numbers by straight lines attached to their respective layers of the sediment column to their left. A selection of the occurring species of foraminifera is listed at the top of the diagram and their percentage frequencies in the different samples visualized by the use of symbols (legend, Fig. 4b). Actual numbers are given for the very poor sample 258. The list is restricted to these abundant or stratigraphically important species. Only 22 of the 37 different species from the Tertiary deposits and 25 of the 74 Quaternary species are presented on the range chart (Fig. 5).
The Quaternary samples were considerably richer in foraminifera than the Tertiary ones. Their foraminiferal content varied from 300 to 13,700 specimens per $100 \mathrm{~g}$ sediment, the average content being nearly 3,000 specimens $/ 100 \mathrm{~g}$ sediment (excluding sample 258). The foraminiferal content of the Tertiary samples varied from 115 to 850 specimens per sample, the average being 300 specimens. This difference might indicate that some of the Tertiary assemblages are reworked or partially decalcified, but on the other hand the foraminifera are well preserved-particularly those of zone TA - with shining glassy tests.

\section{Tertiary}

\section{Foraminiferal zonation}

Zone TA, the Bolivina cf. antiqua zone. - This zone comprises samples $19,20,247,260$, and 248 (Figs. 4 and 5). The samples contain well preserved assemblages, the specimens appearing brownish and glassy. The zone is characterized by common to frequent occurrences of the species Bolivina cf. antiqua d'Orbigny, Baggina cf. dentata Hagn, Cibicides cf. tenellus (Reuss), Pullenia bulloides (d'Orbigny), Nonion granosum (d'Orbigny), and Turrilina alsatica Andreae. More sparsely represented are Alabamina tangentialis (Clodius), Gyroidinoides angustiumbilicatus (Ten Dam), Eponides pygmaeus (Hantken), some species of Cibicides, Gyroidinoides girardanus (Reuss), and Gyroidinoides soldanii (d'Orbigny). Epistominella oveyi (Batjes), Pullenia quinqueloba (d'Orbigny), Angulogerina tenuistriata (Reuss), Angulogerina gracilis (Reuss), Eponides cf. geinitzi (Clodius) and Cassidulinoides subglobosa Brady are occasionally present. The lower part of zone TA (samples 19 and 20) show high frequencies of Cibicides cf. tenellus, whereas its upper part has frequent occurrences of Bolivina cf. antiqua.

Sample 21 (not in the range chart) contained a very poor foraminiferal fauna. It is referred to zone TA with some uncertainty.

Zone TB, the Asterigerina gürichi zone. - This zone (samples 244 and 228 and also 226 and 232) still contains many specimens of Cibicides cf. tenellus and Turrilina alsatica, but differs from zone TA by the appearance and frequent occurrence of Asterigerina gürichi (Franke). Nonion affine and Cassidulinoides subglobosa (Brady) are 


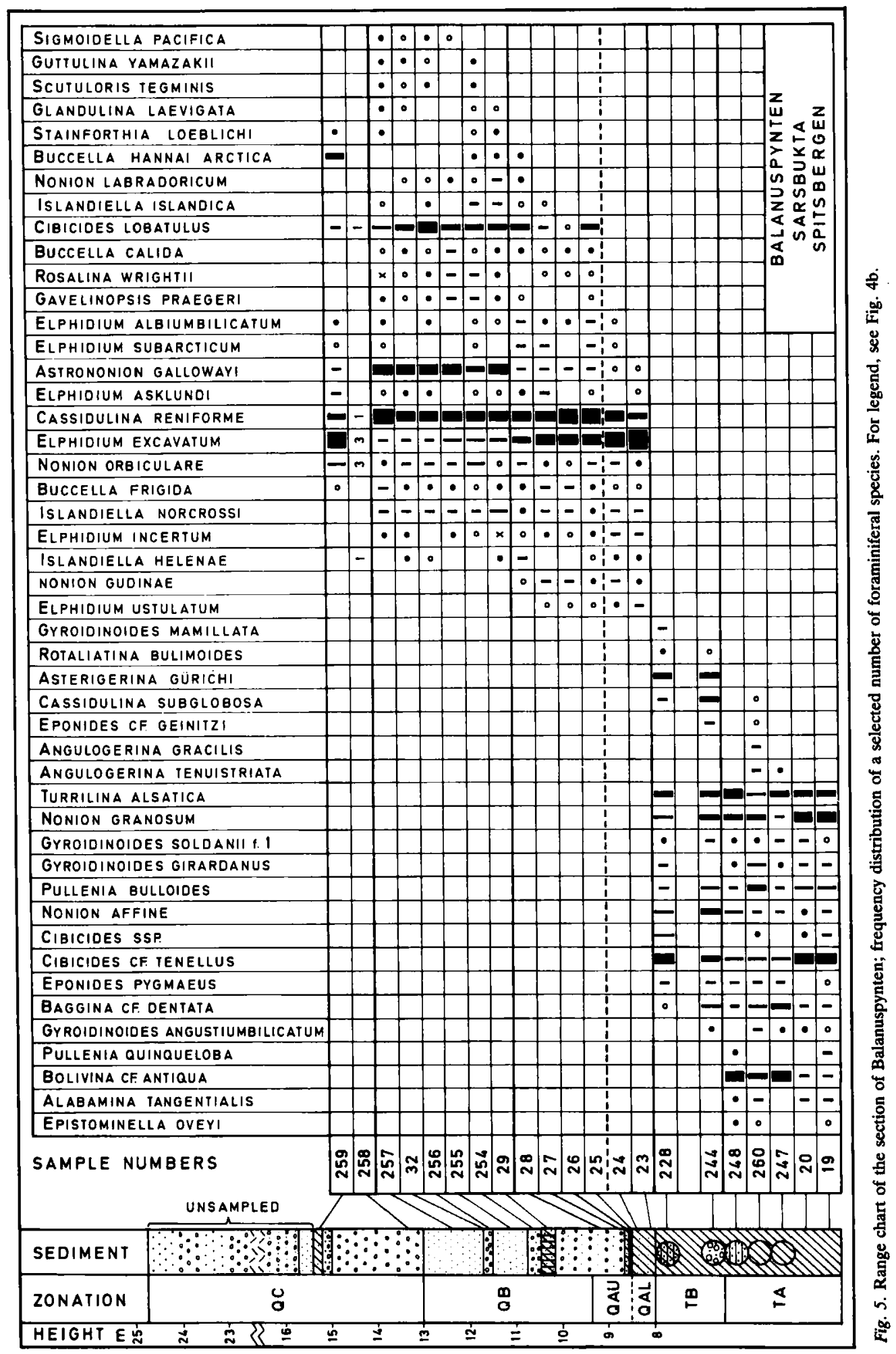


quite frequent in sample 244 , and Rotaliatina bulimoides (Reuss) occurs in both samples (1 specimen in sample 244 and 4 in 228). Gyriodinoides mammilata (Andreae) is present in sample 228 (9 specimens). Bolivina cf. antiqua, frequent in the upper part of zone TA, is absent in zone TB. Samples 226 and 232 are, with some uncertainty, referred to this zone.

\section{Age of zone TA and zone TB}

The species listed above and accessory species occurring in the samples of zone TA and TB are all well known from Oligocene and some of them also from Miocene deposits of Northwest Europe. Turrilina alsatica is, in this part of the world, restricted to Oligocene deposits, particularly to Middle Oligocene where it locally may occur in great abundance, e.g. in Niederrheinische Bucht (Indans 1958), East Germany (Kiesel 1962), The Netherlands (Ten Dam \& Reinhold 1942), Belgium (Batjes 1958), Denmark (Christensen \& Ulleberg 1973, 1974; Ulleberg 1974). Nonion granosum is known from Oligocene to Pleistocene in Central Europe and the Mediterranean area (Marks 1951), and from Oligocene to Miocene in Northwest Europe (Batjes 1958; Grossheide and Trunkó 1965).

Cibicides tenellus is known mainly from Upper Oligocene but also from Middle Oligocene deposits (Ten Dam \& Reinhold 1942; Batjes 1958).

Nonion affine has been recorded mainly from Middle and Upper Oligocene deposits, occurring also in the Lower and Middle Miocene (Ten Dam \& Reinhold 1942; Batjes 1958; Ulleberg 1974; Christensen and Ulleberg 1974).

Pullenia bulloides is common in Danish Middle Oligocene deposits (Christensen \& Ulleberg 1974) and occurs generally in the Middle Oligocene to the Middle Miocene of northwestern Europe. It is even found in Quaternary and Recent deposits (Batjes 1958; Feyling-Hanssen 1964a). Both Gyroidinoides girardanus and Gyroidinoides soldanii seem to have a broad stratigraphical distribution, the first from Eocene to Miocene, the latter from Cretaceous to Recent (Ulleberg 1974). Gyroidinoides girardanus was, though, recorded only from the Rupelian and lowermost Chattian of the Rheintalgraben (Doebl \& Malz 1962), and Eponides pygmaeus is known mainly from the Oligocene and Miocene of Northwest Europe with some occurrences also in the Eocene.
In general, foraminiferal assemblages containing such species as Turrilina alsatica, Rotaliatina bulimoides, Asterigerina gürichi and Gyroidinoides mammilata indicate an Oligocene (Middle/Upper) age in on- and off-shore deposits of the North Sea Basin. Zones TA and TB of Sarsbukta are therefore most probably Middle to Upper Oligocene in age.

The species that occur mainly or only in zone A, viz., Epistominella oveyi, Alabamina tangentialis, Bolivina cf, antiqua, Pullenia quinqueloba, Gyroidinoides angustiumbilicata and Baggina cf. dentata have a similar stratigraphical range. Epistominella oveyi has been recorded from the Eocene to Miocene, Alabamina tangentialis also from the Eocene to Miocene, the distribution of Bolivina cf. antiqua is unknown, Pullenia quinqueloba is known from Palaeocene to Recent, Gyroidinoides angustiumbilicata from Eocene and Oligocene, whereas the distribution of Baggina cf. dentata is also unknown. Baggina dentata was originally described by Hagn (1956) from the Upper Eocene of Italy.

The occurrence of Asterigerina gürichi in zone $B$ is interesting because in Denmark clay with Asterigerina gürichi in abundance is found above clay with a high frequency of Turrilina alsatica (Viborg 1 boring and outcrops at Branden, Faarup; cf. Dam 1976; Lieberkind 1977). The Asterigerina gürichi zone is there considered Chattian in age whereas the Turrilina alsatica zone has been referred to the Rupelian. A similar stratigraphic distribution is found in numerous borings and outcrop localities of the North Sea Basin, where deposits with Asterigerina gürichi overlie sediments with abundant Turrilina alsatica. These sequences are in general considered to be Middle to Upper Oligocene in age, ormore precisely-as belonging to the Middle/ Upper Oligocene transition. Rotaliatina bulimoides is a well established Middle Oligocene marker in the North Sea Basin.

Manum (1960) described dinoflagellates and hystrichosphaerids from sample 260 of the present material, and based on the occurrence of Deflandrea phosphoritica Eisenack, he suggested an Upper Palaeocene to Eocene age. This is in accordance with Ravn's (1922) dating of the main Tertiary basin deposits of Spitsbergen. But $D$. phosphoritica is also known to occur in the Oligocene (cf., e.g., Manum, l.c., p. 19).

Livšic $(1967,1974)$ also considers the Sesshøgda Formation, which most probably comprises the 
Tertiary outcrop described in the present paper, to be of Eocene age and only the stratigraphically overlying Marchaislaguna Formation on Prins Karls Forland to belong in the Oligocene. Kellogg $(1975 ; 479)$ suggests the Tertiary of Forlandsundet to be younger than the Tertiary of the main basin of Svalbard, and mentions Oligocene as a possibility. (See also Atkinson 1963 and Buchardt 1981).

\section{Quaternary}

\section{Foraminiferal zonation}

Zone $Q A$, the Nonion gudinae-Elphidium ustulatum zone. - Six samples, Nos. 23 to 28 , are included in this unit (Fig. 5). The two lowermost samples are from a sandy clay with fragments of mollusc shells. No. 25 is from a thin layer of sandy silt, No. 26 from a layer of sandy clay above, and Nos. 27 and 28 from a coarse sandy yellowishbrown gravel with fragments of short-valved $\mathrm{Hia}$. tella arctica, and of Astarte spp., Mytilus edulis Linné and Arctica islandica.

In spite of the wide range of grain size the composition of the foraminiferal assemblages is quite homogeneous: Elphidium excavatum (Terquem) and Cassidulina reniforme Nørvang are frequent, and Elphidium ustulatum Todd and Nonion gudinae (Feyling-Hanssen) are present. Still the two lowermost samples of the zone differ enough from the other samples to justify a subdivision of the unit into a lower and an upper subzone.

Subzone $Q A L$, the Elphidium ustulatum subzone. - The two samples, Nos. 23 and 24, from the sandy clay at the base of the Quaternary sequence belong to this subumit. Elphidium excavatum dominates both assemblages (63\% in No. 23 , and $53 \%$ in No. 24); Cassidulina reniforme is second in frequency ( $20 \%$ in No. 23 and $28 \%$ in No. 24). Many of the Elphidium excavatum belong to forma excavata (cf. Miller et al. $1982=$ Elphidium excavatum forma selseyensis Feyling-Hanssen 1972), several of them with a large umbilical boss. E. excavatum forma clavata was frequent in the lowest sample. Characteristic among the accessory species are Elphidium ustulatum and Nonion gudinae but also Islandiella helenae Feyling-Hanssen and Buzas, Elphidium incertum (Williamson) and Islandiella norcrossi (Cushman). The latter species is also quite frequently represented in the overlying subzone QAU and in zone QB.

There was a total of 28 species in subzone QAL (21 different species in each of the two samples). The assemblages were well preserved and contained between 870 (No. 23) and 2400 (No. 24) individuals per $100 \mathrm{~g}$ sediment.

Subzone $Q A U$, the Nonion gudinae subzone. This subzone includes the four samples (Nos. 25 to 28) from the upper part of the basal sandy clays (No. 26) and silts (No.25) and the lower part of the overlying $2 \mathrm{~m}$ thick gravel unit (Nos. 27 and 28).

Elphidium excavatum and Cassidulina reniforme are still dominant, but in this subzone $C$. reniforme is more frequent than $E$. excavatum. Only in sample 27 does $E$. excavatum $(37 \%)$ slightly outnumber $C$. reniforme $(34 \%)$. Another characteristic is the appearance and occasional frequent occurrence of Cibicides lobatulus (Walker and Jacob). This species accounts for $16 \%$ of the assemblage in sample 25 and $20 \%$ in sample 28, that is, in samples from sandy silt and sandy gravel. In sample 26 (sandy clay), however, it is very rare, represented by only one specimen. This indicates that its frequency is dependent on the substratum which again in turn is dependent on current velocity or water depth. But in sample 26 , from the lowest part of the sandy gravel, there were only seven specimens, accounting for only slightly more than $2 \%$ of the assemblage. Characteristic of the subzone is a quite constant occurrence of Astrononion gallowayi Loeblich and Tappan (2-5\% of the assemblages), the presence of Elphidium albiumbilicatum (Weiss) (1-2\%), and of Buccella calida (Cushman and Cole). Buccella frigida (Cushman) is present in all the samples of the subzone, Elphidium subarcticum Cushman in three of them. Nonion gudinae is still fairly well represented, but Elphidium ustulatum and Elphidium incertum have become rarer.

Many tests of Elphidium excavatum possess a large umbilical boss. The excavata form as well as the clavata form occur. Some of the specimens from samples 27 and 28 had their latest or later chambers broken.

A total of 36 species were found in this subzone, 22 in sample 25,25 in sample 26,22 in sample 27 , and 22 in sample 28 . The number of foraminiferal specimens per $100 \mathrm{~g}$ sediment is 740 in sample 25,630 in sample 26,300 in sample 27 , and 670 in sample 28 (cf. Fig. 6). 
Zone $Q B$, the Astrononion gallowayi zone. - This unit comprises the six samples (Nos. 29, 254, 255, 256,32 and 257) collected from clayey-sandy silt (No. 29), coarse sand (No. 254), fine sand with mollusc shells (No. 255), fine gravel (No.256), and again fine sand (No. 257). Molluscan shells from this zone (sample 255) gave the ${ }^{14} \mathrm{C}$ minimum age of 40,800 years B.P.

The most characteristic features of zone $\mathrm{QB}$ are low frequencies of Elphidium excavatum, high frequencies (18-28\%) of Astrononion gallowayi and the presence of both Gavelinopsis praegeri (Heron-Allen and Earland) and Rosalina wrightii (Brady). Another characteristic is the presence of large polymorphinids and glandulinids, e.g. Guttulina dawsoni Cushman and Ozawa, G. glacialis (Cushman and Ozawa), G. yamazakii Cushman and Ozawa, Sigmoidella pacifica Cushman and Ozawa, Sigmomorphina undulosa (Terquem), and Glandulinae laevigata d'Orbigny. Cibicides lobatulus is fairly abundant (11-24\%) in all the samples except the uppermost one where it accounted for $8 \%$ of the assemblage. Islandiella norcrossi is constantly represented in zone $\mathrm{QB}$, whilst Islandiella islandica (in four samples) and Nonion labracioricum (in five samples) are also present

Nonion barleeanum (Williamson) has been observed in one of the samples of the zone, and Islandiella inflata (Gudina) in two of them. Cassidulina reniforme $(25-44 \%)$ is dominant over Elphidium excavatum (4-10\%) in all the samples of zone QB.

Forty-eight species of foraminifera have been found in zone QB. The number of specimens per $100 \mathrm{~g}$ sediment averages around 3,200 . The richest sample was No. 29 , from the clayey-sandy silt, with 13,700 specimens in $100 \mathrm{~g}$ sediment.

Twenty-four ostracod valves occurred in sample 257 , including one complete carapace.

Zone $Q C$, the Elphidium excavatum zone. - This zone is represented by only two samples No. 258 from the lower part of a $2 \mathrm{~m}$ thick coarse gravel, and No. 259 from a $20 \mathrm{~cm}$ thick layer of sandysilty clay at $15.3 \mathrm{~m}$ above sea level.

Sample 258 contained only nine specimens in $100 \mathrm{~g}$ sediment, viz. three specimens of Elphidium excavatum, one Cassidulina reniforme, one Islandiella helenae, one Cibicides lobatulus, and three Nonion orbiculare (Brady). The specimens were worn and broken, probably reworked. Sample 259 , on the other hand, contained a rich and well preserved foraminiferal fauna.

The faunal composition of sample 259 differs from those of zone QB by greatly increased frequency of Elphidium excavatum (41\%) and reduced frequency of Cassidulina reniforme (19\%), particularly of Astrononion gallowayi (4\%). The frequency of Cibicides lobatulus has been reduced to less than $3 \%$, and many of the species found in zone QB have disappeared. Nonion orbiculare accounts for $7 \%$ of the assemblage, but in the microscope it is a characteristic element of the fauna with large, white and glistening tests. Large Elphidium asklundi Brotzen are also present, and the small Buccella hannai arctica Voloshinova is frequent $(14 \%)$.

Sample 259 is the only one with agglutinated foraminifera in the present material. It contains seven specimens (1\%) of Tritaxis atlantica (F. L. Parker).

This upper sample was particularly rich in foraminfera, containing 13,300 specimens per $100 \mathrm{~g}$ sediment. The specimens are very well preserved. There was a total of 36 different species.

Elphidium excavatum forma excavata (cf. Miller et al. 1982) occurs in sample 259, but is overshadowed by $E$. excavatum forma clavata (cf. Feyling-Hanssen 1972; Miller et al. 1982).

\section{Palaeoenvironment of the Quaternary deposits}

The foraminiferal unit zones QA to QC represent Quaternary shallow-water deposits. Comparison with Recent foraminiferal faunas described by Nagy (1965) from shallow waters of Hornsund and from the east coast of Spitsbergen and from deeper water (c. $50 \mathrm{~m}$ ) of Kongsfjorden, northeast of Sarsbukta (Elverhøi et al. 1980) suggests that the sediments of zone QC (sample 259) and also of subzone QAL were deposited in the shallowest, coldest and least saline water (probably less than $10 \mathrm{~m}$ ), whereas those of zone QB represent slightly deeper and warmer conditions (probably $20-40 \mathrm{~m}$ ). The rich and diverse assemblages of zone QB may even reflect interglacial conditions. They include some of those species that occur in Spitsbergen waters of the present day (which is an interglacial), and some of them, such as Gavelinopsis praegeri and Rosalina vilardeboana, are mainly of more southerly habitat (Rosset-Moulinier 1972).

Some parameters which may be useful in an attempt to evaluate a palaeoenvironment have been calculated for the investigated Quaternary 


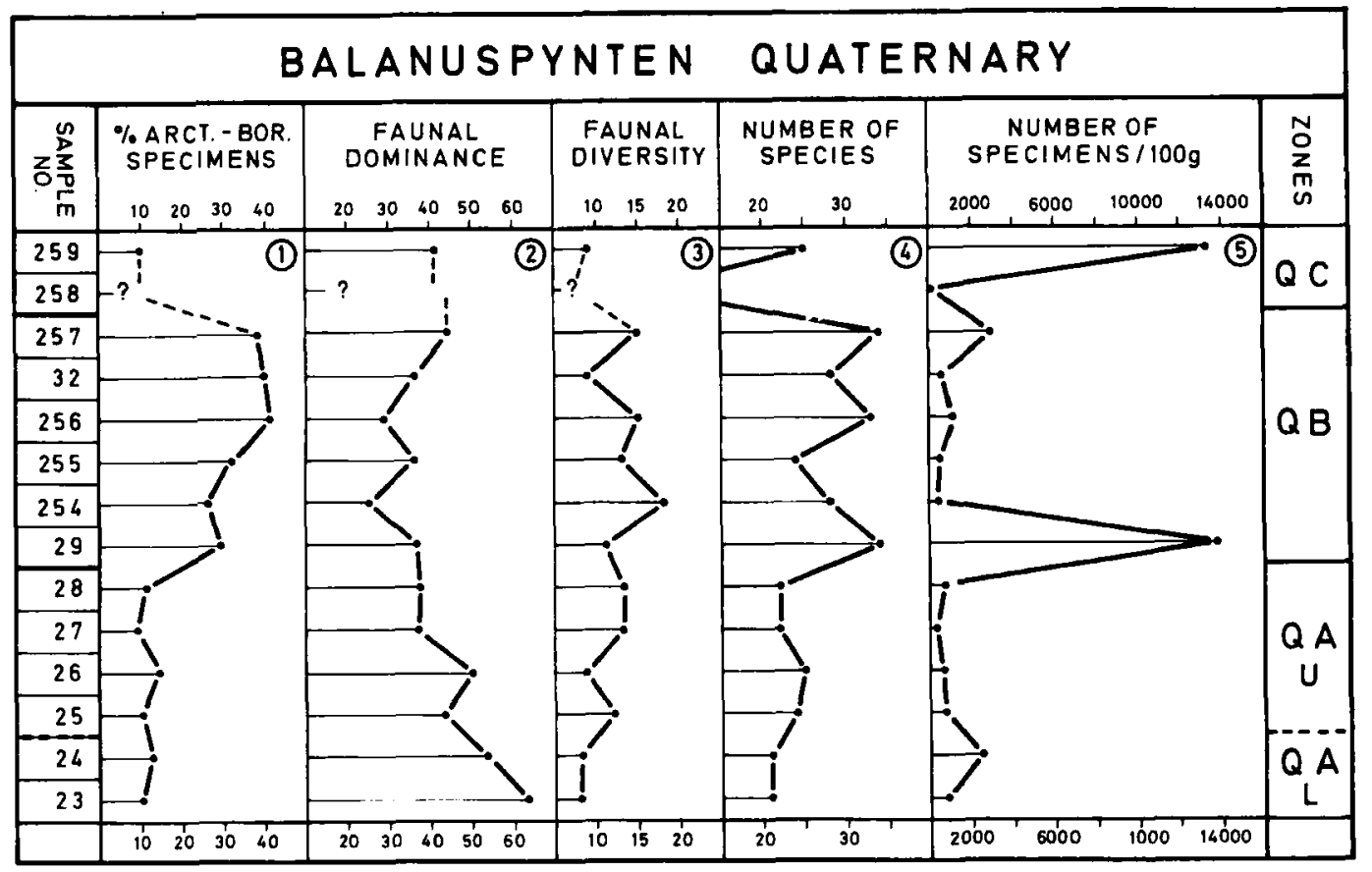

Fig. 6. Palaeocological parameters for the Quaternary part of the section at Balanuspynten.

assemblages and are presented as a series of graphs in Fig. 6.

The first graph illustrates the percentage of arctic-boreal foraminiferal specimens. Gudina $(1966,1976)$ and Gudina \& Evserov (1973) indicated species distributed in arctic but also in boreal waters of the present day as 'arctic-boreal'. Those chosen here constitute a slight modification to Gudina \& Evserov's (1973) list. Among such species Gudina \& Evserov included Cibicides rotundatus Stshedrina, which is very close to Cibicides lobatulus (Walker and Jacob) of the present study. Because of its apparent dependency on the substratum $C$. lobatulus is not included in the arctic-boreal element in Fig. 6. If it had been included the percentages would have attained 65 in sample 256.

Arctic-boreal species do exist in Arctic waters, but they are not confined to the Arctic, and they may not have occurred there during past glacial periods (cf. Feyling-Hanssen 1980). A high percentage of sūch species in an assemblage may indicate ameliorated conditions when the assemblage lived at the locality. The trend of this curve in Fig. 6 shows high percentages within zone QB, largely as a result of high frequencies of Astrononion gallowayi. As this species does occur in
Spitsbergen waters of the present day - even close to the calving termini of glaciers - the value of such a diagram is disputable. However, Astrononion gallowayi is grouped with the arctic-boreal species (Gudina \& Evserov 1973).

On the other hand, high faunal dominance (Walton 1964) and low faunal diversity (Walton 1964) reflect severe conditions (columns 2 and 3 of Fig. 6). High frequencies of the arctic form Elphidium excavatum forma clavata Cushman characterize Weichselian (Wisconsinan) inner shelf deposits (Feyling-Hanssen 1964, 1972, 1981, 1982; Feyling-Hanssen et al. 1971; Gudina 1966, 1969, 1976; Vilks 1981) and also many presentday arctic shallow-water assemblages (FeylingHanssen 1964:149 and 150; Nagy 1965; Elverhøi et al. 1980; Vilks 1969). This form is very frequent in sample 259 (zone QC) at Balanuspynten $(41 \%)$. The faunal diversity is 8 for this assemblage. In the two lowest samples of the Quaternary sequence, samples 23 and 24 (subzone QAL), the frequencies of Elphidium excavatum reach $63 \%$ and $53 \%$ and the faunal diversity is 8 in both assemblages. But many of the Elphidium excavatum of this subzone are large and belong to forma excavata and many possess a large umbilical boss. The excavata form may point to 
somewhat ameliorated conditions or decreased salinity values. It may alsu have something to do with age. Brodniewicz (1972) found such large forms (Guilbault 1980, vol. 2, pp. 234-238, called such forms 'well-developed') in presumed earlyor pre-Eemian deposits of Poland. Osterman (1982) based the 'Proximal glacial' of her environmental facies model on the occurrence of 'a low diversity foraminiferal fauna dominated by Elphidium excavatum f. clavata - varying from 100 to $50 \%$ of the total foraminiferal fauna. This facies indicates very close proximity of glacial ice' (l.c., p. 248). In the present section of Sarsbukta such conditions are found in subzone QAL and again seem to be re-established in the uppermost sample of zone QC. Osterman's 'Distal glacial facies', on the other hand, is characterized by lower percentages of $E$. excavatum $\mathrm{f}$. clavata and higher percentages of Cassidulina reniforme, and her 'Extreme distal facies' in addition is characterized by high diversities and abundances.

These features are also typical of the present zone $\mathrm{QB}$, and partly also of subzone QAU. Thus the environmental facies model of Osterman (1982), reached through investigations in Frobisher Bay, Baffin Island, may support our suggestion of an interglacial environment during the deposition of zone QB.

\section{Age of the Quaternary deposits}

There are no species indicating a Lower Quaternary age for any part of the Quaternary sequence of Balanuspynten, Sarsbukta. The presence of Elphidium ustulatum in zone QA, particularly in subzone QAL (7 specimens in the counted part of sample 23 and 5 in sample 24), may suggest a pre-Eemian or early Eemian age for this zone, as Gregory \& Bridge (1979) found that this species does not occur in any number in Eemian and post-Eemian deposits. The ${ }^{14} \mathrm{C}$ minimum age of sample 255 (>40,800 B.P.) of zone QB may support this. Zone QB, with its rich and ameliorated assemblages, was probably deposited during some part of the penultimate interglacial stage - the Eemian (Sangamonian, Oxygen isotope stage 5 e). Miller (1982), who described similar sections on the peninsula of Brøggerhalvøya, north of Sarsbukta, and also on Prins Karls Forland, found by amino-acid dating that the pre-Holocene deposits there originate from a series of stages of widely different ages within the Quaternary.

If the bivalve shell date of 10,250 B.P. from near Konglomeratodden is accepted as representative also for Balanuspynten, then zone $\mathrm{QC}$ from the upper part of the Quaternary sequence was deposited during the Late Weichselian to Early Flandrian.

Zone QC deposits also occur above the Tertiary part of the section at Konglomeratodden, but the older part of the Quaternary sequence at Balanuspynten (zone QA-QB) is lacking there.

The assemblages of zone $\mathrm{QB}$ at Balanuspynten, Spitsbergen, are remarkably similar to the zone E foraminiferal assemblages of the Qivituq Peninsula in Baffin Island, Arctic Canada (FeylingHanssen 1980). The most frequent and thus characterizing species of both zones are Cassidulina reniforme, Cibicides lobatulus and Astrononion gallowayi and similarity indices (Sanders 1960) between assemblages from the two zones range between 70 and 80 . The Palaeoenvironment must have been fairly similar at both localities and, despite the great distance involved, even a similarity in age might be suggested. For comparison the foraminiferal range chart for the Qivituq Peninsula sections is reproduced here as Fig. 7.

\section{Raised beaches}

At the present locality, between the southern landlocked end of Sarstangen and the northern lateral moraines of Aavatsmarkbreen, Boulton (1979:44) observed and mapped raised marine beaches which he ${ }^{14} \mathrm{C}$ dated using mollusc shells from their deposits. He distinguished two beach sequences, one with an upper limit at $32 \mathrm{~m}$ above present-day sea level and an older one with a marine limit at $50 \mathrm{~m}$. He combined a ${ }^{14} \mathrm{C}$ date at $>34,000$ B.P. for shells from above what he considered a till with the upper (up to $50 \mathrm{~m}$ ) beach sequence and samples with dates at 10,000 12,000 B.P. with the high stand of sea level at $32 \mathrm{~m}$. (In addition he found shells which gave dates between 13,400 and 14,900 B.P.)

Similar observations were made by Salvigsen (1977) from Prins Karls Forland on the western side of Forlandsundet. A lower sequence of beaches extending up to $20 \mathrm{~m}$ above sea level had ages from 9,300 to 12,590 B.P., and an upper series of beaches reaching an altitude of $40 \mathrm{~m}$ were dated at 34,250 to 35,230 B.P. Troitsky $e t$ al. (1979) obtained a ${ }^{14} \mathrm{C}$ date of $28,200 \pm$ 500 B.P. from $8 \mathrm{~m}$ above sea level from the same deposits (cf. Salvigsen \& Nydal 1981).

These observations agree with the present find- 


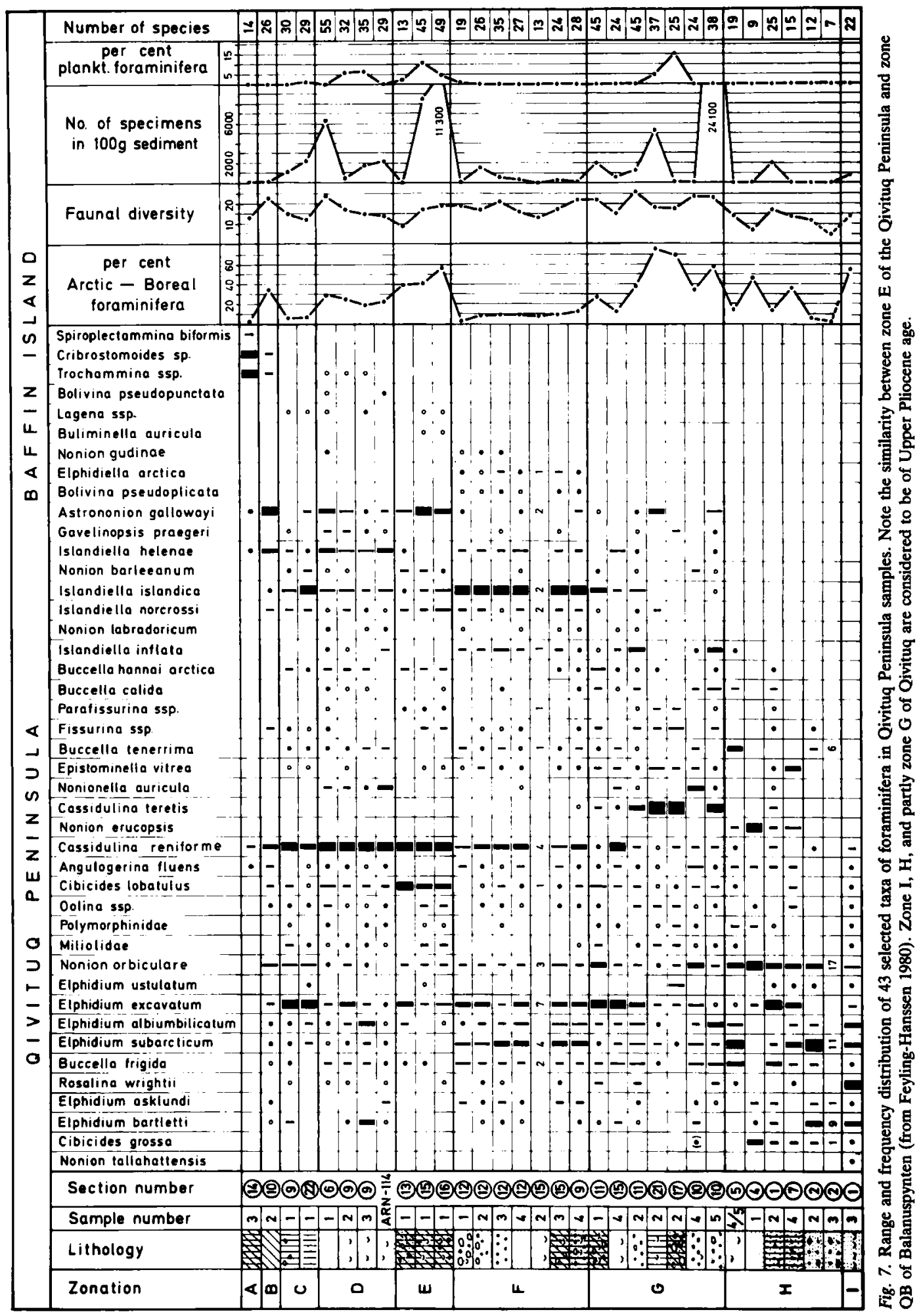




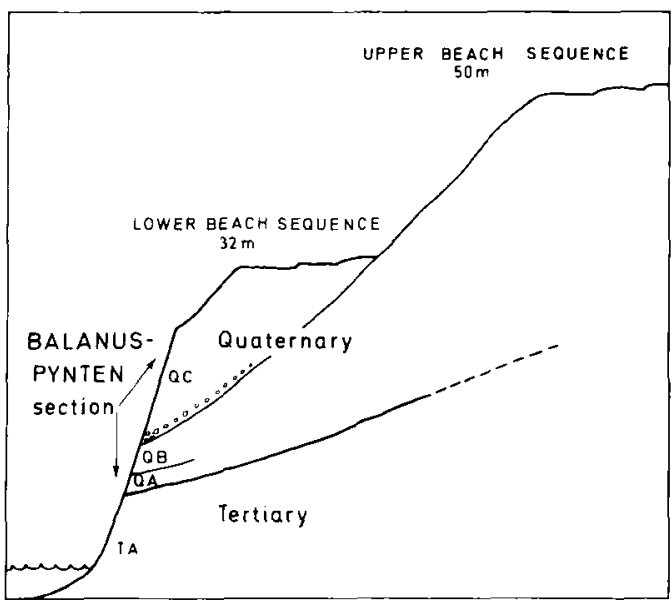

Fig. 8. Schematic cross section of the deposits of Sarsbukta showing the relationship between the raised beaches and the deposits outcropping in the section of Balanuspynten (Cf. Boulton 1979:44 and 46).

ings at Balanuspynten (Fig. 8). The lower part of the Quaternary sequence - zones QA to QB correlates with the older, upper, beach series, whereas the upper part - zone QC - correlates with the lower and younger series of beaches. The shallow-water assemblages of zone QA may reflect a transgressional facies, whereas the somewhat deeper water assemblages of zone QB may have been deposited contemporaneously with the high stand of sea level at $50 \mathrm{~m}$.

A Middle Weichselian age is generally assumed for these older raised beaches. This view is based primarily on numerous ${ }^{1+} \mathrm{C}$ dates but also on uranium series dates and even some amino acid analyses (Salvigsen 1979, 1981; Salvigsen \& Nydal 1981). The concept of a Mid-Weichselian interval of high sea level and subsequent regression would thus seem reasonable.

However, the reliability of ${ }^{1+} \mathrm{C}$-datings on older shell material is disputed (Broecker \& Benden 1971: Salvigsen \& Nydal 1981: Miller 1982). Material from Baffin Island and East Greenland, dated by radiometric methods and also analysed for amino acid ratios and therefore considered Mid-Weichselian of age. turned out to be considerably older when micropalaeontological methods were employed (Feyling-Hanssen 1980; Feyling-Hanssen et al. 1983).

If the above ages from the older, higher beaches landwards from Balanuspynten and those from the northern Prins Karls Forland are considered mere minimum ages, their genesis could be detached from the Middle Weichselian and moved backwards in geological time.

As stated, the foraminifera of zone $Q B$ at Balanuspynten are found living in Spitsbergen waters at the present time, which is an interglacial. The mollusc assemblages occurring in the samples support such a view. The species Arctica islandica, which occurs in zone $\mathrm{QB}$, has previously only been found in Post Glacial Warm Interval deposits in Central Spitsbergen (Feyling-Hanssen 1955a, b). Mytilus edulis also occurs.

Strauch $(1968,1969)$ demonstrated that the adult shell length of Hiatella arctica is closely controlled by water temperature, long (and abundant) shells indicating polar conditions, short (and fewer) shells ameliorated conditions. Hiatella arctica is represented only by short shells in the deposits of zone $Q B$ in the section at Balanuspynten.

Zone QB and its corresponding high sea-level stand and the old beach generation belongs, most probably, somewhere in the penultimate interglacial, the Eemian. Zone QA with Elphidium ustulatum, may represent a Late Saalian to early Eemian transgression.

As to the reasons for the shoreline displacements, glacial-isostatic rebound movements may have played a minor role in a poorly glaciated area such as western Spitsbergen.

\section{Foraminifera}

A total of 37 Tertiary and 74 Quaternary species of foraminifera occurred in the investigated samples from the coastal cliff of Balanusviken, from Balanuspynten to Konglomeratodden. They are listed below and a few remarks are added. Some of them are illustrated in plates 1-4.

Family LITUOLIDAE de Blainville. 1825

Genus Haplophragmoides Cushman, 1910

Haplophragmoides walteri (Grzybowski)

$\sqsupset$ 1898. Trochammina walteri Grzybowski: Akad. Lmiej. Krakowie. Wydz. Mat-Przyr., Rozpr., Krakov. vol. 33. p. 290. pl. 11. fig. 31 .

Two specimens occurred in the Tertiary zone TA.

Genus Tritaxis Schubert. 1921

Tritaxis atlantica (F, Parker)

$\sqsupset$ 1952. Trochamminella atlantica F. Parker; Bull. Mus. Comp. Zool.. vol. 106. No. 9. p. 409. pl. 4. 
Seven specimens occurred in sample 259 of zone QC of the Quaternary.

Family FISHERINIDAE Millett, 1898

Genus Cyclogyra Wood, 1842

Cyclogyra involvens (Reuss)

Pl. 2, fig. 1

1850. Operculina involvens Reuss: Denkschr. Akad. Wiss. Wien, vol. 1. p. 370, pl. 46, fig. 30.

Occurred in subzone QAL.

Family MILIOLIDAE Ehrenberg, 1839

Genus Quinqueloculina d'Orbigny, 1826

Quinqueloculina arctica Cushman

$\square$ 1933, Smithsonian Misc. Coll.89, No.9. p. 2. pl. 1, figs. $3 \mathrm{a}-\mathrm{c}$.

Occurred in the upper part of the Quaternary zone QB.

\section{Quinqueloculina borea Gudina}

$\square$ 1966, Akad. Naùk SSSR, Sibirskoje Otd., Inst. Geol.

Geofiz., Moscow, p. 23, pl. 1, figs. 2-3.

Occurred in subzone QAL.

\section{Quinqueloculina longa Gudina}

口 1969, Akad. Nauk SSSR, Sibirskoje Otd., Inst. Geol. Geofiz. 63, p. 9, pl. 2, figs. 2-4.

Occurred in subzone QAL.

\section{Quinqueloculina seminulum (Linné)}

$\square$ 1758. Serpula seminulum Linné: Systema naturae. Ed. 10 Lipsia 1, p. 786, pl. 2, fig. 1.

Occurred in all samples of zone QA.

Quinqueloculina stalkeri Loeblich and Tappan

$\square$ 1953, Smithsonian Misc. Coll. 121 , No. 7, p. 40 , pl.5, figs. 5-9.

A single specimen in zone $\mathrm{QC}$.

\section{PLATE 1 Tertiary $($ All $\times 75)$}

Fig. 1. Stilostomella hispida (Soldani). Specimen from zone TB.

Figs. 2, 3. Turrilina alsatica Andreae. A specimen from zone TB.

Fig. 4. Angulogerina tenuistriata (Reuss). Specimen from upper part of zone TA.

Figs. 5. 6. Bolivina cf. antiqua d'Orbigny. Two specimens from zone TA.

Figs. 7, 8. Eponides pygmaeus (Hantken). 7, umbilical view; 8, spiral side of a specimen from zone TA.

Figs. 9, 10. Gyroidinoides girardanus (Reuss). Apertural view and spiral side of a specimen from zone TA.

Figs. 11, 12. Baggina cf. dentata Hagn. Umbilical side and spiral side of a specimen from zone TA.

Figs. 13, 14. Gyroidinoides soldanii d'Orbigny forma $l$ Ulleberg. Umbilical view and apertural view of a specimen from zone TA.

Figs. 15, 16. Gyroidinoides girardanus (Reuss). Umbilical view and apertural view of a specimen from zone TA.

Figs. 17, 18. Gyroidinoides girardanus (Reuss). 17, apertural view; 18, umbilical view of a specimen from zone TB.

Figs. 19, 20. Gyroidinoides mamillata (Andreae). Spiral side and apertural view of a specimen from zone TB.

Figs. 21, 22. Cibicides cf. tenellus (Reuss), opposite sides of a specimen from zone TA.

Figs. 23-25. Alabamina tangentialis (Clodius). 23, spiral side; 24, edge view; 25, umbilical side of a specimen from zone TA.

Fig. 26. Nonion granosum (d'Orbigny). Side view of a specimen from zone TA.

Figs. 27, 28. Pullenia bulloides (d'Orbigny). Edge and side of specimen from zone TA.

Figs. 29, 30. Rotaliatina bulimoides (Reuss). 29, oblique umbilical view; 30, spiral side of a specimen from zone TB. 
PLATE 1

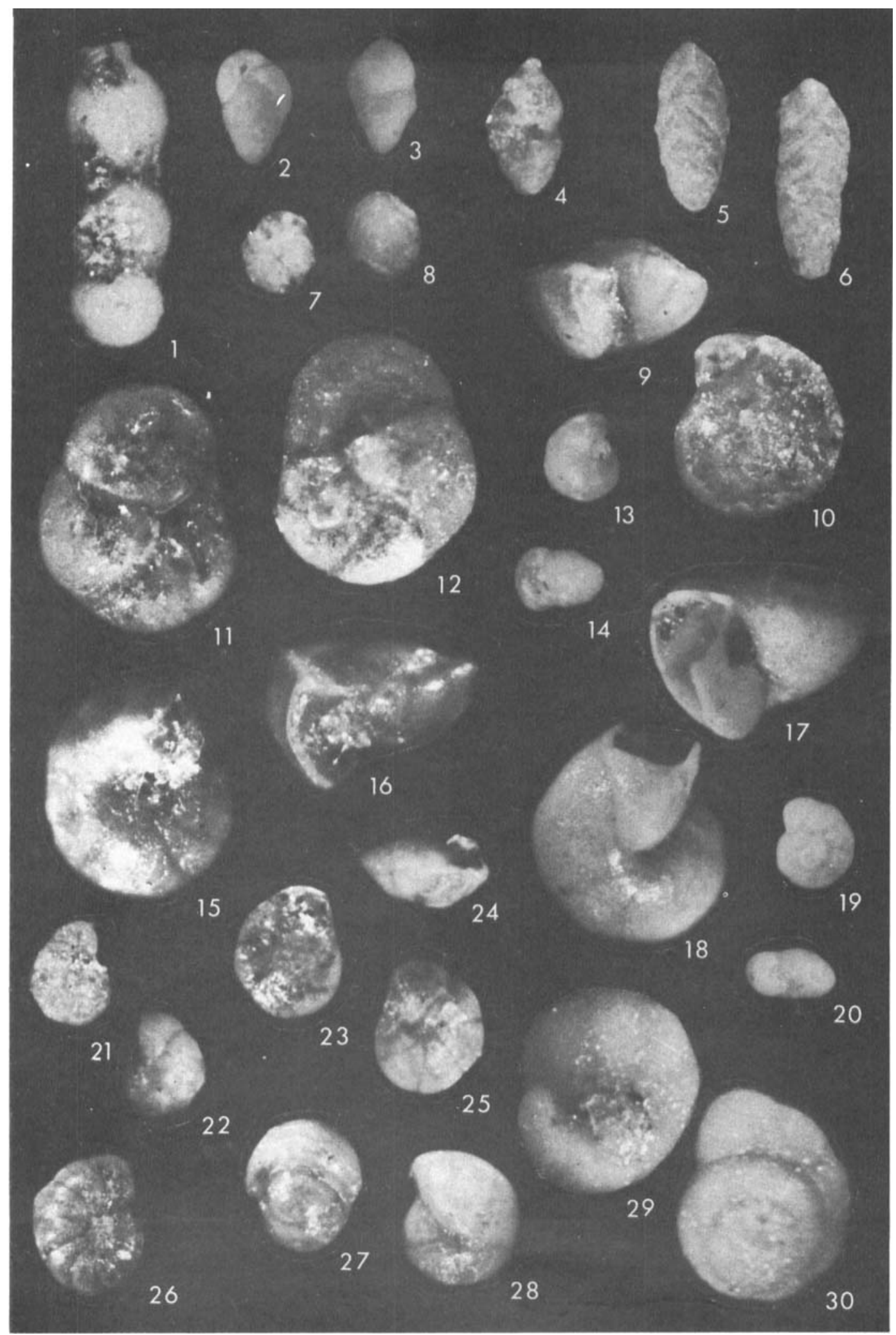


Genus Triloculina d'Orbigny, 1826

Triloculina trihedra Loeblich and Tappan

$\square$ 1953, Smithsonian Misc. Coll. 121, No. 7, p. 45, pl. 4, fig. 10.

Occurred in subzone QAL and in zones QB and QC.

Genus Scutuloris Loeblich and Tappan, 1953

Scutuloris tegminis Loeblich and Tappan

$\square$ 1953, Smithsonian Misc. Coll. 121, No. 7, p. 41, pl. 5, fig, 10.

Present in two samples of zone QB.

Genus Miliolinella Wiesner, 1931

Miliolinella chukchiensis Loeblich and Tappan PI. 2, fig. 2.

$\square$ 1953, Smithsonian Misc. Coll. 121, No. 9, p. 47, pl. 6, figs. 5, 6.

Occurred in subzone QAU and in zone QB.

Miliolinella subrotunda (Montagu)

$\square$ 1803. Vermiculum subrotundum Montagu: Testacea Britannica -, J. S. Hollis (Romsey, England), vol. 2, p. 521. Miliolinella cf. subrotunda (Montagu), Feyling-Hanssen 1964, Norges geol. Unders. Nr. 225, p. 261, pl. 7, fig. 1.

Present in all the zones of the Quaternary part of the section of Balanuspynten.
Family NODOSARIIDAE Ehrenberg, 1838

Genus Dentalina Risso, 1826

Dentalina ittai Loeblich and Tappan

$\square$ 1953, Smithsonian Misc. Coll. 121, No.7, p. 56, pl. 10, figs. $10-12$.

Occurred in zone QB.

\section{Dentalina pauperata d'Orbigny}

$\square$ 1846, Foram. foss. du Bassin Tertiaire de Vienne. Gide et Comp., Paris, p. 46, pl. 1, figs. 57-58.

One specimen occurred in the Tertiary zone TA.

Genus Astacolus De Montfort, 1808

Astacolus hyalacrulus Loeblich and Tappan

$\square$ 1953, Smithsonian Misc. Coll., vol. 121, No. 7, p. 52, pl.9, figs. $1-4$.

A single specimen occurred in sample 254 of zone QB.

Genus Lagena Walker and Jacob, 1798

Lagena elongata (Ehrenberg)

$\square$ 1844. Miliola elongata Ehrenberg: Bericht Verh. Kgl. Preuss. Akad. Wiss. Berlin, p. 274. Lagena elongata (Ehrenberg): Feyling-Hanssen 1964, Norges geol. Unders. Nr. 225, p. 287, pl. 11, fig. 9.

PLATE 2 Quaternary (All $\times 75)$

Fig. 1. Cyclogyra involvens (Reuss). Specimen from subzone QAL.

Fig. 2. Miliolinella chukchiensis Loeblich and Tappan. Specimen from zone QB.

Fig. 3. Guttulina austriaca d'Orbigny. Specimen from subzone QAL.

Fig. 4. Guttulina dawsoni Cushman and Ozawa. Specimen from zone QB.

Figs. 5, 6. Guttulina glacialis (Cushman and Ozawa). Opposite sides of a specimen from zone QB.

Figs. 7, 8. Guttulina yamazakii Cushman and Ozawa. Opposite sides of a specimen from zone QB.

Figs. 9, 10. Glandulina laevigata d'Orbigny. Two specimens from zone QB.

Figs. 11, 12. Bolivina pseudopunctata Høglund. Two specimens from zone QB.

Fig. 13. Oolina hexagona (Williamson). Specimen from zone QC.

Fig. 14. Oolina williamsoni (Alcock). Specimen from zone QC.

Figs. 15, 16. Cassidulina reniforme Nørvang. Opposite sides of a specimen from zone QC.

Figs. 17, 18. Islandiella helenae Feyling-Hanssen and Buzas. Opposite sides of a specimen from zone QB.

Fig. 19. Stainforthia loeblichi (Feyling-Hanssen). Specimen from zone QC. 


\section{PLATE 2}

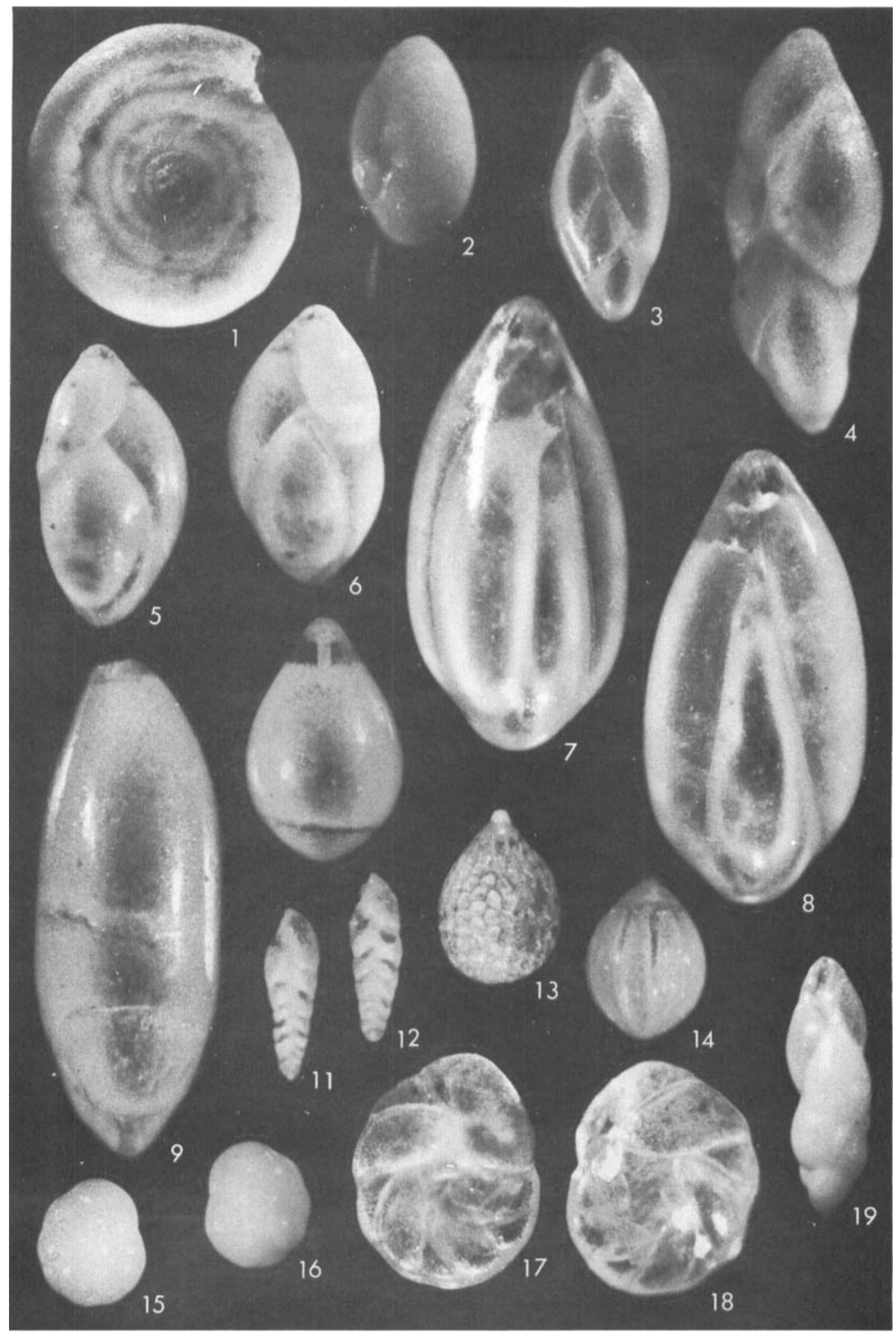


Observed in sample 259 of zone $\mathrm{QC}$ of the Quaternary.

\section{Lagena globosa (Montagu)}

$\square$ 1803. Vermiculum globosum Montagu: Testacea Britannica

-, J. S. Hollis (Romsey, England), p. 523.

Rare in both zones of the Tertiary.

\section{Lagena semilineata Wright}

$\square$ 1886, Proc. Belfast Nat. Field Club, n.s., vol. 1, app.9, p. 320, pl. 26, fig. 7 .

Observed in zone QC of the Quaternary.

\section{Lagena tenuis (Bornemann)}

$\square$ 1855. Ovulina tenuis Bornemann: Deutsches Geol. Ges., Zeitschr., vol. 7(2), Berlin, p. 317, pl. 12, fig. 3.

One specimen in zone TA of the Tertiary.

Family POLYMORPHINIDAE d'Orbigny, 1839

Genus Guttulina d'Orbigny, 1839

Guttulina austriacea d'Orbigny

Pl. 2, fig. 3

$\square$ 1846, Foram. foss. Bassin Tertiaire de Vienne. Gide et Comp., p. 223, pl. 12, figs. 23-25.

Occurred in subzone QAL of the Quaternary.
Guttulina dawsoni Cushman and Ozawa Pl. 2, fig. 4.

$\square$ 1930, U.S. Nat. Mus., Proc., vol. 77(6), p. 47, pl. 12, figs. 1-2.

One specimen in zone $Q B$.

\section{Guttulina frankei Cushman and Ozawa}

$\square$ 1930, U.S. Nat. Mus., Proc., vol. 77(6), p. 28, pl.4, fig. 1a-c.

One specimen in the Tertiary zone TB.

Guttulina glacialis (Cushman and Ozawa)

Pl. 2, figs. 5-6

$\square$ 1930. Globulina glacialis Cushman and Ozawa: U.S. Nat. Mus., Proc., vol. 77(6), p. 71, pl. 15, figs. 6-7.

Occurred in one sample of subzone QAL and in one of zone $\mathrm{QB}$.

\section{Guttulina irregularis (d'Orbigny)}

$\square$ 1846. Globulina irregularis d'Orbigny: Foram. foss. Bassin Tertiaire de Vienne. Gide et Comp., p. 226, pl. 13, figs. 9-10.

Two specimens in the Tertiary zone TA.

\section{Guttulina lactea (Walker and Jacob)}

$\square$ 1798. Serpula lactea Walker and Jacob, in Adams, G.: Essays on the Microscope. Kanmacher. (2nd ed.), p. 634, pl. 14, fig. 4.

\section{PLATE 3 Quaternary (All $\times 75$ )}

Figs. I, 2. Islandiella islandica Nørvang. Opposite sides of specimen from zone QB.

Figs. 3-5. Buccella calida (Cushman and Cole). 3, umbilical side; 4, spiral side; 5, edge view of a specimen from zone $Q B$.

Fig. 6. Islandiella inflata (Gudina). Side view of a specimen from zone $\mathrm{QB}$.

Figs. 7-9. Buccella hannai arctica Voloshinova. 7, spiral side; 8, edge view with aperture; 9, oblique umbilical view of a specimen from zone QC.

Figs. 10, 11. Rosalina vilardeboana d'Orbigny. 10, umbilical side; 11, spiral side of a specimen from zone QB.

Figs. 12-15. Rosalina wrightii (Brady). 12, umbilical side; 13, spiral side of a specimen from zone QB; 14, umbilical side; 15, spiral side of another specimen from zone $\mathrm{QB}$.

Figs. 16-21. Gavelinopsis praegeri (Heron-Allen and Earland). 16, edge with aperture; 17, umbilical side with plug; 18, spiral side of a specimen from zone QB; 19 , edge view; 20 , spiral side; 21 , umbilical side of another specimen from the same zone.

Figs. 22-24. Eoeponidella pulchella (Parker). 22, umbilical side; 23, edge; 24, spiral side of a specimen from zone QC.

Figs. 25-27. Epistominella vitrea Parker. 25, spiral side; 26, edge; 27, umbilical side of a specimen from zone QB.

Figs. 28, 29. Cibicides lobatulus (Walker and Jacob). 28, umbilical side; 29, spiral side of a specimen from zone OC. 


\section{PLATE 3}

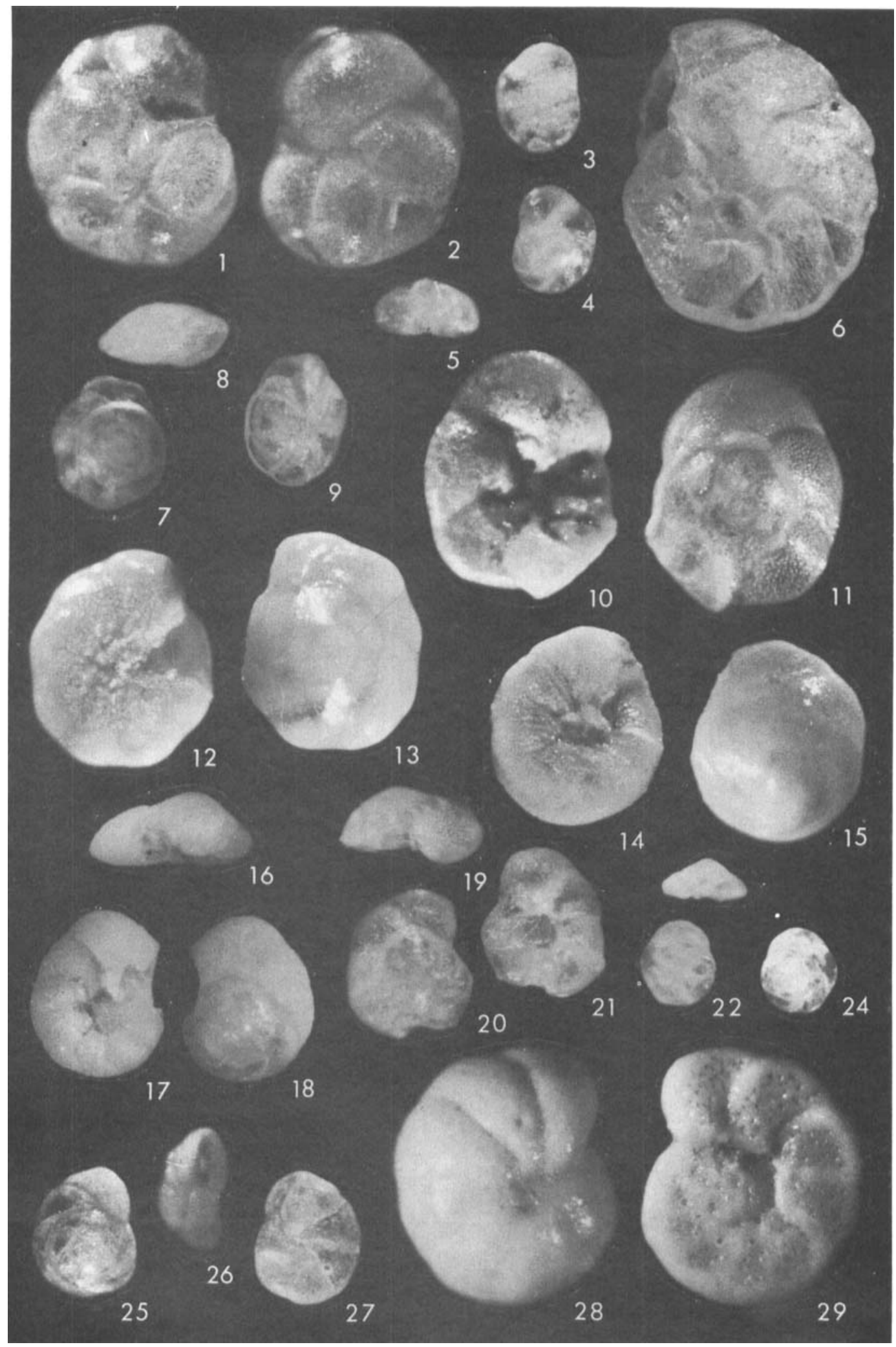


A few specimens in zones $\mathrm{QA}$ and $\mathrm{QC}$ of the Quaternary.

Guttulina yamazakii Cushman and Ozawa Pl. 2, figs. 7-8

$\square$ 1930, U.S. Nat. Mus., Proc., vol. 77(6), p. 40, pl. 8, figs. 3-4.

Accounted for $1 \%$ of the assemblages of three of the samples of zone QB and less than $1 \%$ in one of the samples of the zone.

Genus Globulina d'Orbigny, 1839

Globulina inaequalis Reuss

$\square$ 1850, K. Akad. Wiss. Wien, Math.-Nat. Cl., Denkschr., Bd. 1, p. 377, pl. 48, fig. 9.

Two specimens of this species occurred in the Tertiary zone TA.

\section{Globulina münsteri (Reuss)}

$\square$ 1856. Polymorphina münsteri Reuss: K. Akad. Wiss. Wien, Math.-Nat. Cl., Sitzber., Bd, 18(2), p. 249, pl. 8, fig. 80.

One specimen occurred in zone TA.

Genus Pyrulina d'Orbigny, 1839

Pyrulina cylindroides (Roemer)

$\square$ 1838. Polymorphina cylindroides Roemer: Neues Jahrb. für Min., p. 385, pl. 3, fig. 26.

One specimen in sample 256 and one in sample 32 of the Quaternary zone QB.
Pyrulina fusiformis (Roemer)

$\square$ 1838. Polymorphina fusiformis Roemer: Neues Jahrb. für Min., p. 386, Pl. 3, fig. 37a-b.

One specimen in the Tertiary zone TB.

Genus Sigmoidella Cushman and Ozawa, 1928

Sigmoidella pacifica Cushman and Ozawa

D 1928, Cushman Lab. Foram. Res., Contr. 4, pt. 1, p. 19, pl. 2, fig. 13.

Occurred in four samples of zone QB.

Genus Sigmomorphina Cushman and Ozawa, 1928

Sigmomorphina undulosa (Terquem)

$\square$ 1878. Polymorphina undulosa Terquem: Soc. geol. de France, Mem., Ser. 3, vol. 1, p. 41, pl. 3, fig. 35.

Occurred in one sample of zone QB.

Family GLANDULINIDAE Reuss, 1860

Genus Glandulina d'Orbigny, 1839

Glandulina laevigata d'Orbigny

Pl. 2, figs. 9-10

$\square$ 1826. Nodosaria (Glandulina) laevigata d'Orbigny: Ann. Sci. nat. Paris ser. 1, vol. 7, p. 252, pl. 10, figs. 1-3.

Occurred in four samples of zone QB. These specimens should probably have been referred to Tappanella arctica Gudina and Saidova 1969.

\section{PLATE 4 Quaternary (All $\times 75)$}

Figs. 1, 2. Nonion labradoricum (Dawson). Side view and apertural view of a specimen from zone QB.

Figs. 3-6. Nonion gudinae (Feyling-Hanssen). 3, side with large umbilicus. 4, edge with aperture of a specimen from subzone $\mathrm{QAU} ; 5$, edge view; 6 , side view of another specimen from the same zone.

Figs. 7, 8. Nonion orbiculare (Brady). 7, side view; 8, edge with aperture, specimen from zone QC.

Fig. 9. Astrononion gallowayi Loeblich and Tappan. Side view of a specimen from zone QB.

Figs. 10, 11. Elphidium albiumbilicatum (Weiss). 10, edge view; 11, side view of a specimen from zone QB.

Figs. 12, 13. Elphidium excavatum (Terquem) forma clavata cushman. 12, side view; 13, edge view of a specimen from zone QC.

Figs. 14, 15. Elphidium asklundi Brotzen. Edge with aperture and side of a specimen from zone QC.

Fig. 16. Elphidium incertum (Williamson). Side view of a specimen from subzone QAL.

Figs. 17, 18. Elphidium subarcticum Cushman. Edge and side view of a specimen from zone QB.

Figs. 19, 20. Elphidium ustulatum Todd. Edge and side view of a specimen from subzone QAL. 


\section{PLATE 4}

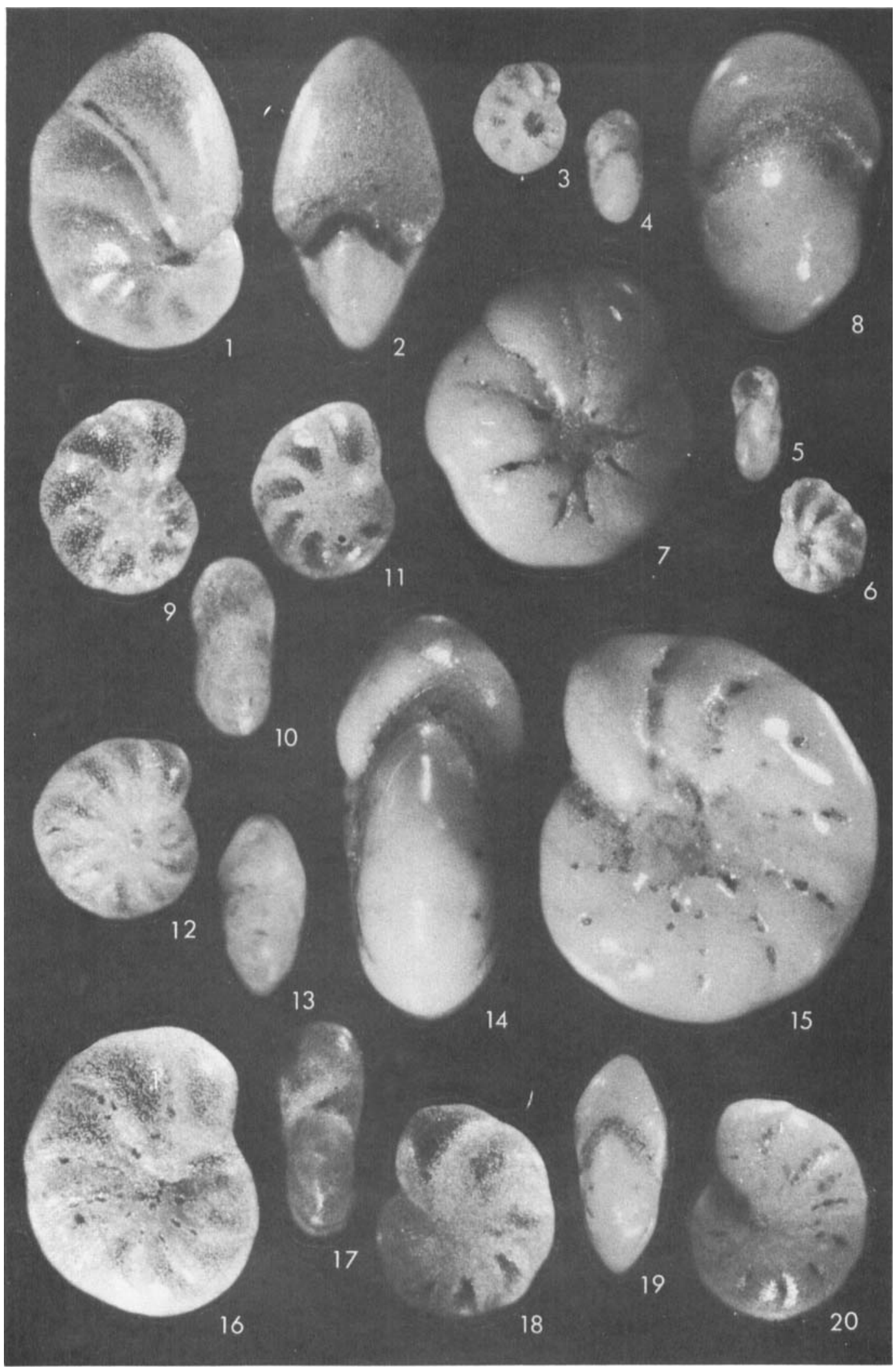


Genus Laryngosigma Loeblich and Tappan, 1953 Laryngosigma williamsoni (Terquem)

$\square$ 1878. Polymorphina williamsoni Terquem: Soc. geol. de France, Mem., Ser. 3, vol. 1, p. 37. Laryngosigma williamsoni (Terquem) Loeblich and Tappan, 1953; Smithsonian Misc. Coll., vol. 121, p. 84, pl. 16, fig. 1.

One specimen of this species occurred in the counted part of sample 256 and two in sample 32 of the Quaternary zone QB.

Genus Oolina d'Orbigny, 1839

Oolina acuticosta (Reuss)

$\square$ 1862. Lagena acuticosta Reuss: K. Akad. Wiss. Wien, Math.-Nat. Cl., Sitzber., Bd. 44, Abth. 1, p. 305, pl. 1, fig. 4.

Occurred in four samples of zone QB.

Oolina borealis Loeblich and Tappan

$\square$ 1954, Washington Acad. Sci., Jour., vol. 44, no. 12, p. 384 (new name for Oolina costata (Williamson), Loeblich and Tappan, 1953: Smithsonian Misc. Coll., vol. 121, No. 7, p. 68, pl. 13, figs. 4-6).

Occurred in the uppermost investigated sample (No. 259) of zone QC.

\section{Oolina caudigera (Wiesner)}

$\square$ 1931. Lagena (Entosolenia) globosa (Montagu) var. caudigera Wiesner: Deutsche Südpolar-Exp. 1901-1903, vol. 20 (Zool., vol. 12).p. 119, pl. 18, fig. 214.

Occurred in sample 259 of zone QC.

\section{Oolina hexagona (Williamson)}

Pl. 2, fig. 13

$\square$ 1848. Entosolenia squamosa (Montagu) var. hexagona Williamson: Ann. Mag. Nat. Hist., ser. 2, vol. 1. p. 20, pl. 2, fig. 23.

Occurred in the uppermost investigated sample (No. 259) of zone QC.

\section{Oolina lineata (Williamson)}

$\square$ 1848. Entosolenia lineata Williamson: Ann. Mag. Nat. Hist, ser. 2, vol. 1, p. 18, pl. 2, fig. 18.

Occurred in sample 29 of zone QB.

\section{Oolina melo d'Orbigny}

$\square$ 1839, Voy. l'Amerique merid., Foram., vol. 5, pt. 5, p. 20, pl. 5. fig. 9.

Occurred in subzone QAU and zone QB.

Oolina williamsoni (Alcock)

Pl. 2, fig. 14 $\square$ 1865. Entosolenia williamsoni Alcock: Proc. Lit. Philos. Soc. Manchester, vol. 4, p. 193.

Observed in the upper sample of zone QC.

Genus Fissurina Reuss, 1850

Fissurina cucurbitasena Loeblich and Tappan

$\square$ 1953, Smithsonian Misc. Coll., vol. 121, No. 7, p. 76, pl. 14, figs. 10-11.

Observed in one sample of subzone QAU.

\section{Fissurina laevigata Reuss}

$\square$ 1850, K. Akad. Wiss. Wien, Math.-Nat. C., Denkschr., Bd. 1, p. 366, pl. 46, fig. 1.

Observed in one sample of zone QB.

\section{Fissurina ventricosa (Wiesner)}

$\square$ 1931. Lagena (Entosolenia) marginata var. ventricosa Wiesner: Deutsche Südpolar-Exp., 1901-1903, vol. 20 (Zool., vol. 12), p. 120, pl. 19, fig. 222.

Observed in one sample of zone $\mathrm{QB}$.

\section{Genus Parafissurina Parr, 1947}

Parafissurina tectulostoma Loeblich and Tappan

$\square$ 1953, Smithsonian Misc. Coll., vol. 121, No. 7, p. 81, pl. 14. fig. 17.

Observed in one sample of zone QB.

Family BULIMINIDAE Jones, 1875

Genus Turrilina Andreae, 1884

Turrilina alsatica Andreae

Pl. 1, figs. 2-3

$\square$ 1884, Geol. Spezialk.-Karte Elsass-Loth. Abh., Bd. 2(3), p. 120, pl. 8, fig. 18.

This species was frequent in the Tertiary deposits of Balanusviken, both in zone TA and TB.

Genus Stainforthia Hofker, 1956

Stainforthia loeblichi (Feyling-Hanssen)

Pl. 2, fig. 19

$\square$ 1954. Virgulina loeblichi Feyling-Hanssen: Norsk Geol. Tidsskr., vol. 33, p. 191, pl. 1, figs. 14-18; text-fig. 3.

Occurred in zone $\mathrm{QB}$ and zone $\mathrm{QC}$.

\section{Stainforthia schreibersiana (Czjzek)}

$\square$ 1848. Virgulina schreibersiana Czjzek: Haidinger's Nat. wiss. Abh. 2, p. 147, pl. 13, figs. 18-21.

Occurred in zone QC. 
Family EOUVIGERINIDAE Cushman, 1927

Genus Stilostomella Guppy, 1894

Stilostomella hispida (Soldani)

Pl. 1, fig. 1

$\square$ 1798. Orthoceratia hispida Soldani: Testaceographiae ac Zoophytographiae parvae et microscopicae, vol.1(3), p. 15, pl. 2, fig. 31P, pl. 11, fig. f.

A few specimens occurred in the Tertiary zones $\mathrm{TA}$ and TB.

\section{Stilostomella longiscata (d'Orbigny)}

$\square$ 1846. Nodosaria longiscata d'Orbigny: Foram. foss. du Bassin Tertiaire de Vienne. Gide et Comp., Paris, p. 32, pl.1, figs. 10-12.

Fragments of this species occurred in the Tertiary zones of Balanusviken.

\section{Family UVIGERINIDAE Haeckel, 1894}

Genus Angulogerina Cushman, 1927

Angulogerina fluens Todd

$\square$ 1947, Cushman Lab. Foram. Res., Contr. 23, pt. 3, p. 67, pl. 16. figs. 6-7.

Occurred in two samples of zone QA and in all the samples of zone QB of the Quaternary part of the section of Balanuspynten.

\section{Angulogerina gracilis (Reuss)}

$\square$ 1851. Uvigerina gracilis Reuss: Deutsch. Geol. Ges., Zeitschr., Berlin, Bd. 3. p. 77.

Occurred in sample 260 of the Tertiary zone TA.

Angulogerina tenuistriata (Reuss)

Pl. 1, fig. 4

$\square$ 1870. Uvigerina tenuistriata Reuss: K. Akad. Wiss. Wien, Math.-Nat. Cl., Sitzber., Bd. 62(1), p. 485, pl. 22, figs. 34-37.

Occurred in two samples of the Tertiary zone TA.

\section{Family BOLIVINITIDAE Cushman, 1927}

Genus Bolivina d'Orbigny, 1839

Bolivina cf. antiqua d'Orbigny

Pl. 1, figs. 5-6

$\square$ 1846. Bolivina antiqua d'Orbigny: Foram. foss. du Bassin Tertiaire de Vienne. Gide et Comp., Paris, p. 240, pl. 14, figs. 11-13.
This species was common in all the samples of the Tertiary zone TA, most frequent in the upper part of the zone. Characteristic of the present specimens is a large number of chambers, straight oblique sutures and a tendency to become twisted in larger specimens.

Bolivina pseudoplicata Heron-Allen and Earland

$\square$ 1930, J. Roy. Micr. Soc., London, (3), vol. 50, p. 81, pl. 3, figs. $36-40$.

Observed in one sample of subzone QAU.

\section{Bolivina pseudopunctata Höglund}

Pl. 2, figs. 11-12

$\square$ 1947. Zool. Bidr. från Uppsala, vol. 26, p. 273, pl. 24, fig. 5; pl. 32, figs. 23-24; text-figs. 280, 281, 287.

Occurred in the zones $\mathrm{QA}$ and $\mathrm{QB}$ of the Quaternary.

\section{Family CASSIDULINIDAE d'Orbigny, 1839}

Genus Cassidulina d'Orbigny, 1826

Cassidulina oblonga Reuss

$\square$ 1850, K. Akad. Wiss. Wien, Math.-Nat. Cl., Denkschr., Bd. 1, p. 376, pl. 48, figs. 5-6.

Observed in zone TB.

\section{Cassidulina reniforme Nørvang \\ Pl. 2, figs. 15-16}

$\square$ 1945. Cassidulina crassa d'Orbigny, var. reniforme Nørvang: The zoology of Iceland, Foram. Munksgaard (Copenhagen and Reykjavik) 2(2), p. 41, text-figs. 6 c-h. Cassidulina subacuta Gudina - Feyling-Hanssen 1976, Arctic and Alpine Res., vol. 8, No. 2, p. 176; Maritime Sediments Spec. Pub. 1, p. 354, pl. 2 , figs. 14-19; 1980, Marine Micropaleontology, vol. 5, p. 180 pl. 4, figs. 12-14.

This species was frequent in the Quaternary subzone QAL and zone QC, and dominant in all the other samples from the Quaternary part of the section.

\section{Cassidulina subglobosa Brady}

$\square$ 1884, Rep. Voy. Challenger, Zoology 9, p. 430, pl. 54, figs. 17 a-c.

Quite frequent in two of the samples of the Tertiary zone $\mathrm{TB}$, rare in TA.

Genus Islandiella Nørvang, 1958

Islandiella helenae Feyling-Hanssen and Buzas

PI. 2, figs. 17-18 
$\square$ 1976, J. of Foraminiferal Res., vol. 6(2), p. 156, figs. 1-4.

Occurred in zone QA and zone QB. A single specimen was found also in the almost barren sample 258 of zone QC.

\section{Islandiella inflata (Gudina)}

Pl. 3, fig. 6

$\square$ 1966. Cassidulina inflata Gudina: Akad. Nauk SSSR, Sibirskoje Otd., Inst. Geol. Geofiz., Moscow, 63, pl. 6, figs. 4-6; pl. 7, fig. 1. Cassandra inflata (Gudina), Gudina, Saidova and Troitskaja, 1968, Dokl. Akad. Nauk SSSR, vol. 182, no. 1, zool., p. 226, fig. 1b.

Observed in the two uppermost samples of zone QB.

\section{Islandiella islandica (Nørvang) \\ Pl. 3, figs. 1-2}

$\checkmark$ 1945. Cassidulina islandica: The zoology of Iceland, Foram. Munksgaard (Copenhagen and Reykjavik) 2(2), p. 42, fig. 7. Islandiella islandica (Nørvang), Nørvang, 1958; Vidensk. Meddr. dansk naturh. Forening, vol. 120, p. 27, pl. 6, figs. 1-5; pl. 7, figs. 6-7.

Occurred in the uppermost samples of subzone QAU and in four samples of zone QB. In the two lowest samples of zone QB it accounted for $2 \%$ (No. 29) and $4 \%$ (No. 254) of the assemblages.

\section{Islandiella norcrossi (Cushman)}

$\square$ 1933. Cassidulina norcrossi Cushman: Smithsonian Misc. Coll. 89, No. 9, p. 7, pl. 2, fig. 7 .

Not frequent, but firmly represented in zones QA and QB.

Family CERATOBULIMINIDAE Cushman, 1927

Genus Lamarckina Berthelin, 1881

Lamarckina haliotidea (Heron-Allen and Earland)

$\square$ 1911. Pulvinulina haliotidea Heron-Allen and Earland: J. Roy. Micr. Soc., London, p. 138, pl. 11, figs. 11. Lamarckina haliotidea (Heron-Allen and Earland), Cushman, 1948: Cushman Lab. Foram. Res. Spec. Publ. No. 23, p. 71, pl. 8, figs. 5 a-c.

Occurred in the uppermost sample of zone QB.

Family SPIRILLINIDAE Reuss, 1862

Genus Patellina Williamson, 1858

Patellina corrugata Williamson

$\square$ 1858, Ray Society, London, p. 46, pl. 3, figs. 86-89.
Occurred, sparsely, in all the zones of the Quaternary part of the section of Balanuspynten.

Family DISCORBIDAE Cushman, 1927

Genus Buccella Andersen, 1952

Buccella calida (Cushman and Cole)

Pl. 3, figs. 3-5

$\square$ 1930. Eponides frigida (Cushman), var. calida Cushman and Cole: Cushman Lab. Foram. Res., Contr., vol. 6, pt. 4, p. 98, pl. 13, fig. 13. Buccella frigida (Cushman), var. calida (Cushman and Cole), Feyling-Hanssen, 1976: Maritime Sediments Spec. Publ. 1, p. 353, pl. 1, figs. 6-7; pl. 2, figs. 7-9.

Occurred in subzone QAU and in zone $Q B$ of the Quarternary part of the section.

\section{Buccella frigida (Cushman)}

$\square$ 1922. Pulvinulina frigida Cushman: Contr. Canadian Biol., 1921 (1922), p. 12 (144). Buccella frigida (Cushman), Loeblich and Tappan, 1953: Smithsonian Misc. Coll., vol. 121, No. 7, p. 115 , pl. 22 , figs. $2-3$.

Occurred in all the zones of the Quaternary part of the section.

\section{Buccella hannai arctica Voloshinova}

Pl. 3, figs. 7-9

$\square$ 1960. Buccella hannai (Phleger and Parker), subsp. arctica Voloshinova: Microfauna SSSR, sb. 11, Trudi, VNIGRI, vol. 153, p. 286, pl. 8, figs. 2-4.

Occurred in subzone QAU and zone QB and was frequent in the uppermost sample of zone $\mathrm{QC}$.

\section{Buccella tenerrima (Bandy)}

$\square$ 1950. Rotalia tenerrima Bandy: Paleont., vol. 24(3), Tulsa, Okla., p. 278, pl. 42, fig. 3.

A few specimens occurred in subzone QAL, and a single specimen in zone QB of the Quaternary sequence.

Genus Rosalina d'Orbigny, 1826

Rosalina vilardeboana d'Orbigny

Pl. 3, figs. 10-11

$\square$ 1839, Voy. l'Amerique Merid. Foram., vol. 5. pt. 5, p. 44, pl. 6, figs. 13-15.

One specimen occurred in subzone QAU and four in zone QB of the Quaternary part of the section.

\section{Rosalini wrightii (Brady)}

Pl. 3, figs. 12-15

$\square$ 1881. Discorbina wrightii Brady: Quart. J. Microsc. Sci., vol. 21, p. 413, pl. 21, fig. 6 . 
Common in zone QB, occurring also in subzone QAU.

Genus Gavelinopsis Hofker, 1951

Gavelinopsis praegeri (Heron-Allen and Earland) Pl. 3, figs. 16-21

$\square$ 1913. Discorbina praegeri Heron-Allen and Earland: Roy. Irish Acad., Proc., vol. 31, pt. 64, p. 122, pl. 10, figs. 8-10.

Common in zone QB, rare in subzone QAU in the section of Balanuspynten.

Genus Eponides De Montfort, 1808

Eponides cf. geinitzi (Clodius)

$\square$ 1922. Pulvinulina geinitzi Clodius: Ver. Freunde Naturg. Mecklenburg, Archiv, Gustrow, Jahr 75, p. 136, pl. 1, figs. 13 a-b.

Occurred in one sample of zone TA and in one of zone TB.

Eponides pygmaeus (Hantken)

Pl. 1, figs. 7-8

$\square$ 1875. Pulvinulina pygmaea Hantken: K. Ungar. Geol. Anst., Mitt. Jahrb., Budapest, vol. 4(1), p. 78, pl. 10, figs. 8 a-b.

Occurred in all samples but one of the Tertiary part of the section.

Genus Eoeponidella Wickenden, 1949

Eoeponidella pulchella (Parker)

Pl. 3, figs. 22-24.

$\square$ 1952. Pninaella (?) pulchella Parker: Bull. Harward Mus. Comp. Zool., vol. 106, p. 421, pl. 6, figs. 18-20.

Eight specimens of this species occurred in zone QC (sample 259). It was not observed in other samples of the section of Balanuspynten.

Genus Epistominella Husezima and Maruhasi, 1944

Epistominella oveyi (Bhatia)

$\square$ 1955. Pseudoparella oveyi Bhatia: J. Pal., vol. 29(4), p. 684, pl. 66, fig. 29; text-fig. 7 .

A few specimens occurred in zone TA.

Epistominella vitrea Parker

PI. 3, figs. 25-27

$\square$ 1953, in Parker, Phleger and Peirson: Cushman Found. Foram. Res. Spec. Publ. 2, p. 9, pl. 4, figs. 34-36, 40-41.

This species was rare but occurred in all the samples of zone QA and QB except samples 28 and 29. It was absent in zone QC.
Genus Alabamina Toulmin, 1941

Alabamina tangentialis (Clodius)

Pl. 1, figs. 23-25

$\square$ 1922. Pulvinulina tangentialis Clodius: Ver. Freunde Naturg. Mecklenburg. Archiv, Gustrow, Jahr. 75, p. 138, pl. 1, fig. 14.

Occurred in four samples of zone TA.

Genus Baggina Cushman, 1926

Baggina cf. dentata Hagn

Pl. 1, figs. 11-12

$\square$ 1956. Palaeontographica, Stuttgart, vol. 107, pt. A. nos. 36, p. 165 , pl. 15 , fig. 7 a-b.

This species occurred in all samples of the Tertiary zone TA, a single specimen also in sample 228 of zone TB. The tooth-like hyaline thickening in the umbilical area is not as distinct in the present specimens as described by Hagn.

Genus Gyroidinoides Brotzen, 1942

Gyroidinoides angustiumbilicata (Ten Dam)

$\square$ 1944. Gyroidina angustiumbilicata Ten Dam: Mededel. geol. Sticht. Ser. C.V-No. 3, Maastricht, p. 117, pl. 4, fig. 7.

Occurred in four samples of zone TA, and in one of zone TB.

Gyroidinoides girardanus (Reuss)

PI. 1, figs. 9-10, 15-18

$\square$ 1851. Rotaiatina girardana Reuss: Deutsch. Geol. Gesellsch.. Zeitschr., vol. 3, p. 73, pl. 5, fig. 34 .

Occurred in all samples of zone TA and in one of zone TB.

\section{Gyridinoides mamillata (Andreae)}

Pl. 1, figs. 19-20

$\square$ 1884. Rotalia girardana (Reuss) var. mamillata Andreae: Geol. Spezialkarte Elsass-Loth., Abh., vol. 2(3), p. 234, pl.9, fig. 4 .

Occurred in sample 228 of the Tertiary zone TB.

Gyridinoides soldanii d'Orbigny forma 1 Ulieberg PI. 1, figs. 13-14

$\square$ 1974, Bull. Geol. Soc. Denmark, vol. 33, p. 283, pl.8, figs. 1-2.

Occurred in all samples of the Tertiary of Balanusviken.

Genus Rotaliatina Cushman, 1925

Rotaliatina bulimoides (Reuss)

Pl. 1, figs. 29-30 
$\square$ 1851. Rotalia bulimoides Reuss: Deutsch. Geol. Gesellsch., Zeitschr., Berlin, vol. 3, p. 77, pl. 5, fig. 38.

A few specimens of this species occurred in the Tertiary zone TB.

Family ASTERIGERINIDAE d'Orbigny, 1839

Genus Asterigerina d'Orbigny, 1839

Asterigerina gürichi (Franke)

$\square 1912$. Discorbina gürichi Franke: Hamburg Wiss. Anst., vol. 29 (1911), p. 29, fig. 130, text-fig. 8.

This species was characteristic of the Tertiary zone TB.

Family PLANORBULINIDAE Schwager, 1877

Genus Cibicides Montfort, 1808

Cibicides aknerianus (d'Orbigny)

$\square$ 1846. Rotalina akneriana d'Orbigny: Foram. foss. du Bassin Tertiaire de Vienne. Gide et Comp., Paris, p. 156, pl. 8, figs. 13-15.

Three specimens occurred in zone TA.

Cibicides lobatulus (Walker and Jacob)

PI. 3, figs. 28-29

$\square$ 1798. Nautilus lobarulus Walker and Jacob, in G. Adams: Essays on the Microscope. F. Kanmacher (2nd ed.), London, p. 642, pl. 14, fig. 36 .

This species was frequent ( $8 \%$ to $24 \%$ ) in all the samples of zone QB, and also frequent in two samples of subzone QAU. It attained its highest frequency in the sandy gravel of sample 256 and was rare in the sandy clay of sample 26 . It did not occur in subzone QAL, and accounted only for $1.5 \%$ of the assemblage of sample 259 (zone $\mathrm{QC})$.

\section{Cibicides telegdi Grossheide and Trunk6}

$\square$ 1965, Geol. Jahrb., Beih., Hannover, no. 60, p. 157, pl. 14, fig. 10 a-c; text-fig. 18.

Nine specimens of this species occurred in zone $\mathrm{TA}$, one in zone TB.

\section{Cibicides cf. tenellus (Reuss)}

Pl. 1, figs. 21-22

$\square$ 1865. Truncatulina tenella Reuss: K. Akad. Wiss. Wien, Math.-Naturw. Cl., Sitzber., Wien, Bd. 50, Abt. 1 (1864), p. 477 , pl. 5 , fig. 6 .
Fairly frequent in all the samples of the Tertiary of Balanusviken. They have quite a high umbilical side.

\section{Cibicides ssp.}

Some small and indeterminable specimens of Cibicides occurred in zone TA and zone TB.

Family NONIONIDAE, Schultze, 1854

Genus Nonion Montfort, 1808

Nonion affine (Reuss)

$\square$ 1851. Nonionina affinis Reuss: Deutsch. Geol. Gesellsch., Zeitschr., Berlin, vol. 3, p. 72, pl. 5, fig. 32.

This species occurred in all the samples of the Tertiary zones TA and TB. It was most frequent in sample 244 of zone TB, where it accounted for $12 \%$ of the assemblage.

\section{Nonion barleeanum (Williamson)}

$\square$ 1858. Nonionina barleeanum Williamson: Ray Society, London, p. 32, pl. 3, figs. 68-69.

This species was observed in two samples from zone QB of the Quaternary part of the section of Balanuspynten.

\section{Nonion granosum (d'Orbigny)}

Pl. 1, fig. 26

$\square$ 1846. Nonionina granosa d'Orbigny: Foram. foss. du Bassin Tertiaire de Vienne. Gide et Comp., Paris, p. 110, pl. 5, figs. 19-20.

This species occurred in all samples of the Tertiary of Balanusviken. It was particularly frequent in the two lowest samples of zone TA where it accounted for $27 \%$ (sample 19) and $24 \%$ (sample 20) of the assemblages.

\section{Nonion gudinae (Feyling-Hanssen)}

Pl. 4, figs. 1-2

$\square$ 1976. Protelphidium gudinae Feyling-Hanssen: 1st Internat. Symp. on Benthonic Foraminifera of Continental margins, Pt. B: Paleoecology and Biostratigraphy, Maritime Sediments, Spec. Publ. 1, p. 359, pl. 5, figs. 13-14.

This species occurred in all samples of the Quaternary zone QA.

\section{Nonion labradoricum (Dawson)}

Pl. 4, figs. 1-2

$\square$ 1860. Nonionina labradorica Dawson: Canadian Nat., vol. 5, p. 191, text-fig. 4 . 
This species occurred in the uppermost sample of subzone QAU and in all but one of the samples of zone QB. It was not frequent.

\section{Nonion orbiculare (Brady)}

PI. 4, figs. 7-8

$\square$ 1881. Nonionina orbicularis Brady: Ann. Mag. Nat. Hist., ser. 5 , vol. 8, p. 415, pl. 21, fig. 5.

This species occurred in all the samples from the Quaternary part of the section of Balanuspynten. It was most frequent $(3.4 \%)$ in the sandy gravel of sample 256 (zone QB) and in the sandy clay of sample 259 (zone QC) where it accounted for $7.1 \%$ of the assemblage.

\section{Nonion pompilioides (Fichtel and Moll)}

$\square$ 1798. Nautilus pompilioides Fichtel and Moll: Camesina, Wien, p. 31, pl. 2, figs. a-c.

Two specimens in zone TB.

Genus Astrononion Cushman and Edwards, 1937 Astrononion gallowayi Loeblich and Tappan Pl. 4, fig. 9

1953, Smithsonian Misc. Coll., vol. 121, No. 7, p. 90, pl. 17, figs. 47.

This species occurred in all samples of the Quaternary part of the section of Balanuspynten except the almost barren sample 258 . It was characteristic of zone QB where it accounted for $17.7 \%$ to $36.0 \%$ (average $24.7 \%$ ). In subzone QAU its average frequency was $2.9 \%$, and it was rare in subzone QAL.

Genus Pullenia Parker and Jones, 1862

Pullenia bulloides (d'Orbigny)

Pl. 1, figs. 27-28

$\square$ 1846. Nonionina bulloides d'Orbigny: Foram. foss. du Bassin Tertiaire de Vienne. Gide et Comp., Paris, p. 107, pl. 5, figs. 9-10.

Occurred in all samples of the Tertiary of Balanusviken.

\section{Pullenia quinqueloba (Reuss)}

$\square$ 1851. Nonionina quinqueloba Reuss: Deutsch. Geol. Gesellsch., Zeitschr., Berlin, vol. 3, p. 71, pl. 5, fig. 31.

Nine specimens occurred in zone TA.
Family ELPHIDIIDAE Galloway, 1933

Genus Elphidium Montfort, 1808

Elphidium albiumbilicatum (Weiss)

Pl. 4, figs. 10-11

$\square$ 1954. Nonion pauciloculum Cushman, subsp. albiumbilicatum Weiss: U.S. Geol. Surv., Prof. Pap. 254-G, p. 157, pl. 32, figs. 1-2.

Occurred in small numbers in all units of the Quaternary part of the section of Balanuspynten. It was extremely rare in subzone QAL.

\section{Elphidium asklundi Brotzen}

Pl. 4, figs. 14-15

$\square$ 1943, in Hessland: Bull. Geol. Inst. Upsala, vol. 31, p. 267, figs. 109-111.

A few specimens of this species occurred in all units of the Quaternary part of the section of Balanuspynten.

\section{Elphidium bartletti Cushman}

$\square$ 1933, Smithsonian Misc. Coll., vol. 89, No.9, p. 4, pl. 1 , fig. 9.

Occurred in sample 28 of subzone QAU and sample 254 of zone QB of the Quaternary of Balanuspynten.

\section{Elphidium excavatum (Terquem)}

Pl. 4, figs. 12-13

$\square$ 1876. Polystomella excavata Terquem: Soc. Dunkerquoise, Mém., vol. 19 (1874-1875), p. 429, pl. 2, figs. 2 a-d.

This species occurred in all the samples of the Quaternary part of the section of Balanuspynten. It was particularly frequent in subzone QAL and again in sample 259 of zone QC. In this latter sample Elphidium excavatum forma clavata Cushman dominated the population, whereas some specimens of $E$. excavatum forma excavata (Terquem) $(=E$. excavatum forma selseyensis of Feyling-Hanssen, 1972; cf. Miller et al. 1982:182) occurred in zone QA. This ameliorated form dominated the Elphidium excavatum population of zone QB. Some large specimens (forma magna? Miller, Scott and Medioli) occurred in zones $\mathrm{QA}$ and $\mathrm{QB}$.

\section{Elphidium frigidum Cushman}

$\square$ 1933, Smithsonian Misc. Coll., vol. 89, No. 9, p. 5, pl. 1, fig. 8.

A few specimens referable to this species occurred in samples 24,25 , and 26 . They are close to Elphidium subarcticum Cushman. 
Elphidium incertum (Williamson)

Pl. 4, fig. 16

$\square$ 1858. Polystomella umbilicatula var, incerta Williamson: Ray Society, London, p. 44, pl. 3, fig. 82a.

This species occurred in zones $Q A$ and $Q B$ of the Quaternary of Balanuspynten. In subzone QAL it made $3.9 \%$ and $4.7 \%$ of the assemblages. Some specimens of Elphidium asklundi may be confused with this species.

\section{Elphidium subarcticum Cushman \\ Pl. 4, figs. 17-18}

$\square$ 1944, Cushman Lab. Foram. Res., Spec. Publ., 12, p. 27, pl. 3, figs. 34-35.

This species occurred in three of the samples from subzone QAU, accounting for $1.7 \%$ to $3.7 \%$ of the assemblages. It was rare in the other units of the Quaternary of Sarsbukta.

\section{Elphidium ustulatum Todd}

Pl. 4, figs. 19-20

$\square$ 1957, U.S. Geol. Surv. Prof. Pap. 294-F, p. 230, pl. 28, fig. 16.

Occurred only in the Quaternary zone QA, rare in the upper subzone $\mathrm{QAU}$, less rare $(1.8 \%$ $1.3 \%$ ) in subzone QAL.

\section{Genus Elphidiella Cushman, 1936 Elphidiella arctica (Parker and Jones)}

$\square$ 1864. Polystomella arctica Parker and Jones: in H. B. Brady, Trans. Linn. Soc., London, Zool., vol. 24, p. 471, pl. 48, fig. 18.

Two specimens of this species occurred in sample 254 of the Quaternary zone QB.

Acknowledgements. - We gratefully acknowledge the help of Otto Salvigsen, the Norwegian Polar Research Institute, Oslo, Hans-Petter Serjrup, University of Bergen, and Jeno Nagy, University of Oslo, who read the manuscript and suggested valuable improvements. We extend our thanks to Svend Meldgaard, who processed the samples and provided the photographs for the plates, to Jette Gissel Nielsen, who prepared the drawings, and to Lissi Østerhaab Mogensen, who kindly arranged the manuscript - all of the Department of Micropaleontology, Aarhus University. David N. Penney of the University of Dublin kindly corrected the English language.

\section{References}

Atkinson, K. J. 1963: Tertiary rocks of Spitsbergen. Am. Assoc. Petr. Geol. Bull. 47, 302-323.

Batjes, D. A. J. 1958: Foraminifera of the Oligocene of Belgium. Koninklijk Belgisch Inst. Naturw. Verh. 143, 1-188.
Boulton, G. S. 1979: Glacial history of the Spitsbergen archipelago and the problem of a Barents Shelf ice sheet. Boreas 8, 31-57.

Boulton, G. S., Baldwin, C. T., Peacock, J. D., McCabe, A. M., Miller, G., Jarvis, J., Horsefield, B., Worsley, P., Eyles, N., Chroston, P. N., Day, T. E., Gibbard, P., Hare, P. E. \& Brunn, V. von 1982: A glacio-isostatic facies model and amino acid stratigraphy for late Quaternary events in Spitsbergen and the Arctic. Nature 298, 437-441.

Brodniewicz, I. 1972: Pleistocene foraminifers of the area of the Lower Vistula River (Northern Poland). Acta Palaeont. Polonica 17(4), 423-525. Warszawa.

Broecker, S. \& Bender, M. L. 1971: Age determination on marine strandlines. Lamont-Doherty Geological Observatory Contr. 1679, 19-35.

Buchardt, B. 1982: Tertiary deposits of the Norwegian-Greenland sea region (Svalbard, Northeast and East Greenland, Iceland, the Faeroe Islands and the Norwegian Greenland Sea) and their correlation to Northwest Europe. Pp. 585-610 in Kerr, J. W. \& Ferguson, A. V. (Eds.): Geology of the North Atlantic Borderlands. Mem. J. Canadian Soc. Petr. Geol, Calgary.

Christensen, L. \& Ulleberg, K. 1973: Sedimentology and micropaleontology of the Middle Oligocene sequence a: Sofienlund - Denmark. Bull. geol. Soc. Denmark 22, 283305.

Christensen, L. \& Ulleberg, K. 1974: Sediments and foraminifers of the Middle Oligocene Viborg Formation, Denmark. Bull. geol. Soc. Denmark 23, 109-117.

Dam, T. 1976: Foraminiferer og stratigrafi i oligocaene aflejringer ved Faarup (Mellem Randers og Hobro, Jylland), 1-2. Unpublished thesis, Geol Inst. Aarhus University. 189 pp.

Doebl, F. \& Malz, H. 1962: Tertiär des Rheintal-Grabens. Leitfossilien der Mikropaläontologi, 379-385. Gebrüder Borntraeger, Berlin 1962.

Elverhøi, A., Liestøl, O. \& Nagy, J. 1980: Glacial erosion, sedimentation and microfauna in the inner part of Kongsfjorden, Spitsbergen. Nor. Polarinist. Skr. 172, 33-60.

Feyling-Hanssen, R. W. 1955a: Stratigraphy of the marine Late-Pleistocene of Billefjorden, Vestspitsbergen. Nor. Polarinst. Skr. 107, 1-186.

Feyling-Hanssen, R. W. 1955b: Late-Pleistocene deposits at Kapp Wijk, Vestspitsbergen. Nor. Polarinst. Skr. 108, 1-21.

Feyling-Hanssen, R. W., 1964a: Foraminifera in Late Quaternary deposits from the Oslofjord area. Nor. geol. Unders. 225, 1-383.

Feyling-Hanssen, R. W. 1964b: A marine section from the Holocene of Talavera on Barentsøya in Spitsbergen, with a record of the Foraminifera. Vorträge des Fridtjof-NansenGedächtnis-Symposions über Spitsbergen 3-11 April 1961 im Würzburg, 30-58. Steiner Verlag, Wiesbaden (Nor. Polarinst. Medd. 93, Oslo 1965).

Feyling-Hanssen, R. W. 1964c: Probleme du soulevement des terres autour de la Mer de Barentz. Vorträge des FridtjofNansen-Gedächtnis-Symposions über Spitzbergen 3-11 April 1961, 68-72. F. Steiner Verlag, Wiesbaden, 1964.

Feyling-Hanssen, R. W. 1965: Shoreline displacement in central Vestspitsbergen and a marine section from the Holocene of Talavera on Barentsøya in Spitsbergen. Nor. Polarinst. Medd. 93, 1-34.

Feyling-Hanssen, R. W. 1972: The foraminifer Elphidium excavatum (Terquem) and its variant forms. Micropal. 18(3), 337-354.

Feyling-Hanssen, R. W. 1976: The Clyde Foreland Formation, a micropaleontological study of Quaternary stratigraphy. Ist 
Int. symp. on Benthonic Foraminifera of Continental Margins, Pt. B: Paleoecology and Biostratigraphy. Maritime Sediments, Spec. Pub. 1, 315-377.

Feyling-Hanssen, R. W. 1980: Microbiostratigraphy of young Cenozoic marine deposits of the Qivituq Peninsula, Baffin Island. Marine Micropaleontology 5, 153-184.

Feyling-Hanssen, R. W. 1981: Foraminiferal indication of Eemian interglacial in the northern North Sea. Bull. geol. Soc. Denmark 29, 175-189.

Feyling-Hanssen, R. W. 1982: Foraminiferal zonation of a boring in Quaternary deposits of the northern North Sea. Bull. geol. Soc. Denmark 31, 29-47.

Feyling-Hanssen, R. W., Funder, S. \& Petersen, K. 1983: The Lodin Elv Formation; a Plio-Pleistocene occurrence in Greenland. Bull. geol. Soc. Denmark 31, 81-106.

Feyling-Hanssen, R. W., Jørgensen, J. A., Knudsen, K. L. \& Andersen, A.-L. L. 1971: Late Quaternary Foraminifera from Vendsyssel, Denmark and Sandnes, Norway. Bull. geol. Soc. Denmark 21(2-3), 67-317.

Feyling-Hanssen, R. W. \& Olsson, I. 1960: Five radiocarbon datings of Post Glacial shorelines in central Spitsbergen. Nor. Geogr. Tidsskr. 17, 122-131. Also Nor. Polarinst. Medd. 86.

Gregory, D. \& Bridge, V. A. 1979: On the Quaternary foraminferal species Elphidium? ustulatum Todd, 1957: Its stratigraphic and paleoecological implications. J. Foram. Res. 9(1), 70-75.

Grossheide, K. \& Trunkó, L. 1965: Die Foraminiferen des Doberges bei Bünde und von Astrup mit Beiträgen zur Geologie dieser Profile (Oligozän, N.W. Deutschland). Beih. Geol. Jb. 60, 1-213.

Gudina, V. I. 1966: Foraminifera and stratigraphy of the Northwest Siberian Quaternary, Akad. Nauk SSSR, Siberian dept., Inst. Geol. and Geoph. U.D.K.563.12 (119) (571.1). (In Russian). 132 pp.

Gudina, V. I. 1969: The marine Pleistocene of Siberian lowlands. Foraminifera of the north part of Yenisei's lowland. Academy of Science SSSR. Siberian Department. Works of the Institute of Geology and Geophysics 63. 1-80.

Gudina, V. I. 1976: Foraminifera, stratigraphy, and paleozoogeography of the marine Pleistocene of the northern U.S.S.R. Akad. Nauk SSSR, Siberian Branch, Trud. Inst. Geol. Geoph. 314. $126 \mathrm{pp}$.

Gudina, V. I. \& Evserov, U. Y. 1973: Stratigraphy and foraminifera of Late Pleistocene of Kola Peninsula. 'Nauka' Siberian Branch, Trans. Inst. Geol. Geoph. Iss. 175, 1-148. Novosibirsk.

Guilbault, J.-P. 1980: A Stratigraphic Approach to the Study of the Late-Glacial Champlain Sea Deposits with Use of the Foraminifera. Unpublished thesis, Geological Institute, Aarhus University, Denmark 1-2. 294 pp.

Hagn, H, 1956: Geologische und paläontologische Untersuchungen im Tertiär des Monte Brione und seiner Ungebung (Gardasee, Ober-Italien). Palaeonotgraphica 107, 67-210.

Holtedahl, O. 1913: Zur Kenntnis der Karbonlagerungen des westlichen Spitzbergens. II. Allgemeine stratigraphische und tectonische Beobachtungen. Vid. selsk. Skr., Mat.Nat.KL.23, 1-94.

Indans, J. 1958: Mikrofaunistische Korrelationen im marinen Tertiär der Niederrheinischen Bucht. Fortschr. Geol. Rheinl. u. Wesif. 1, 223-238.

Kellogg, H. E. 1975: Tertiary stratigraphy and tectonism in Svalbard and continental drift. Am. Assoc. Petrol. Geol. Bull. 59(3), 465-485.

Kiesel, Y. 1962: Die oligozänen Foraminiferen der Tiefbohrung Dobbertin (Mecklenburg). Freib. Forsch. H.C.122, 1-123.
Lieberkind, K. 1977: Ostracodstratigrafi $i$ 申verste Eocan og. Oligocan i Danmark. Unpublished thesis Geol. Inst., Aarhus University I-II. 257 pp.

Livకic, J. J. 1967: Tertiary deposits of the western part of the Archipelago of Spitsbergen (Russian). Mat.-ly po stratigrafii Spicbergena (ed. V. N. Sokolov). Nauc.-issl. Inst. Geol. Arktiki, 185-204. Leningrad.

Livšic, J. J, 1974: Palaeogene deposits and the platform structure of Svalbard. Nor. Polarinst. Skr. 159, 1-50.

Manum, S. 1960: Some dinoflagellates and hystericosphaerids from the Lower Tertiary of Spitsbergen. Nor. Polarinst. Medd. 85, 17-25.

Marks, P. 1951: A revision of the smaller foraminifera from the Miocene of the Vienna Basin. Contr. Cushman Found. Foram. Research 2, 33-73.

Miller, A. A. L., Scott, D. B. \& Medioli, F. S. 1982: Elphidium excavatum (Terquem): Ecophenotypic versus subspecific variation. J. Foram. Res. 12(2), 116-144.

Miller, G. H. 1982: Quaternary depositional episodes, western Spitsbergen, Norway: Amino-stratigraphy and glacial history. Arctic and Alpine Research 14(4), 321-340.

Nagy, J. 1965: Foraminifera in some bottom samples from shallow waters in Vestspitsbergen. Nor. Polarinst. Árbok 1963, 109-125.

Osterman, L. E. 1982: Late Quaternary History of Southern Baffin Island, Canada: A Study of Foraminifera and Sediments from Frobisher Bay. Unpublished Ph.D. thesis, University of Colorado, Department of Geological Sciences. $378 \mathrm{pp}$.

Ravn, J. P. J. 1922: On the Mollusca of the Tertiary of Spitsbergen. Result. norske statsunderst. Spitsbergen eksp. 1(2), 1-28. Kristiania.

Rosset-Moulinier, M. 1972: Étude des foraminifères des côtes nord et Ouest de Bretagne. Travaux du Lab. de géologie, École Normale Superieure, 46 rue d'Ulm, Paris. 225 pp.

Salvigsen, O. 1977: Radiocarbon datings and the extension of the Weichselian ice-sheet in Svalbard. Nor. Polarinst. Arsbok 1976, 209-224.

Salvigsen, O. 1979: The last deglaciation of Svalbard. Boreas $8,229-231$.

Salvigsen, O. 1981: Radiocarbon dated raised beaches in Kong Karls Land, Svalbard, and their consequences for the glacial history of the Barents Sea area. Geografiska Ann. 63A, 283-291.

Salvigsen, O. \& Nydal, R. 1981: The Weichselian glaciation in Svalbard before 15,000 B.P. Boreas 10, 433-446.

Salvigsen, O. \& Österholm, H. 1982: Radiocarbon dated raised beaches and glacial history of the northern Spitsbergen coast, Svalbard. Polar Research 1, 97-115.

Sanders, H. L. 1960: Benthic studies in Buzzards Bay. III. The structure of the soft-bottom community. Limnol. Oceanogr. 5(2), 138-153.

Sorgenfrei, Th. \& Buch, A. 1964: Deep Tests in Denmark 1935-1959. Geol. Surv. Denmark III Ser., No. 36, 1-46.

Strauch, F. 1968: Determination of Cenozoic sea temperatures using Hiatella arctica (Linné). Palaeogeogr. Palaeoclimat. Palaeoecol. 5, 213-233.

Strauch, F. 1969: The influence of climate on the adult size of Recent and fossil Hiatella arctica (Linné) and its importance for determination of paleotemperature. Malacologia $9(1)$, 291-292.

Ten Dam, A. \& Reinhold, Th. 1942: Die stratigraphische Gliederung des Niederländischen Oligo-Miozäns nach Foraminiferen. Meded. geol. Stichting, Ser. C.V.2, 1-106.

Troitsky, L., Punning, J.-M., Hütt, G. \& Rajamäe, R. 1979: Pleistocene glaciation chronology of Spitsbergen. Boreas 8 , 401-407. 
Ulleberg, K. 1971: En faunistisk-stratigrafisk undersøkelse av oligocene foraminiferer $i$ Sofienlund, Midt-Jylland. Unpublished thesis, Geological Inst., Aarhus University. $121 \mathrm{pp.}$

Ulleberg, K. 1974: Foraminifera and stratigraphy of the Viborg Formation in Sofienlund, Denmark. Bull. Geol. Soc. Denmark 23, 269-292.

Vilks, G. 1969: Recent foraminifera in the Canadian Arctic. Micropal. 15(1), 35-60.

Vilks, G. 1981: Late glacial-postglacial foraminiferal boundary in sediments of Eastern Canada, Denmark and Norway. Geoscience Canada 8(2), 48-55.

Walton, W. R. 1964: Recent foraminiferal ecology and paleoecology. Pp. 151-237 in Imbrie, J. \& Newell, N. D. (eds.): Approaches to Paleoecology, Wiley \& Sons, New York.

\section{List of foraminifera}

\section{TERTIARY}

Alabamina tangentialis (Clodius)

Angulogerina gracilis (Reuss)

Angulogerina tenuistriata (Reuss)

Asterigerina gürichi (Franke)

Baggina cf. dentata Hagn

Bolivina cf. antiqua d'Orbigny

Cassidulina oblonga Reuss

Cassidulina subglobosa Brady

Cibicides aknerianus (d'Orbigny)

Cibicides telegdi Grossheide and Trunkó

Cibicides cf. tenellus (Reuss)

Cibicides ssp.

Dentalina pauperata d'Orbigny

Epistominella oveyi (Bhatia)

Eponides cf. geinitzi (Clodius)

Eponides pygmaeus (Hantken)

Globulina inaequalis Reuss

Globulina münsteri.(Reuss)

Guttulina frankei Cushman and Ozawa

Guttulina irregularis (d'Orbigny)

Gyroidinoides angustiumbilicata (Ten Dam)

Gyroidinoides girardanus (Reuss)

Gyroidinoides mamillata (Andreae)

Gyroidinoides soldanii d'Orbigny forma 1 Ulleberg

Haplophragmoides walteri (Grzybowski)

Lagena globosa (Montagu)

Lagena tenuis (Bornemann)

Nonion affine (Reuss)

Nonion granosum (d'Orbigny)

Nonion pompilioides (Fichtel and Moll)

Pullenia bulloides (d'Orbigny)

Pullenia quinqueloba (Reuss)

Pyrulina fusiformis (Roemer)

Rotaliatina bulimoides (Reuss)

Stilostomella hispida (Soldani)

Stilostomella longiscata (d'Orbigny)

Turrilina alsatica Andreae

\section{QUATERNARY}

Angulogerina fluens Todd

Astacolus hyalacrulus Loeblich and Tappan

Astrononion gallowayi Loeblich and Tappan

Bolivina pseudoplicata Heron-Allen and Earland

Bolivina pseudopunctata Höglund

Buccella calida (Cushman and Cole)
Buccella frigida (Cushman)

Buccella hannai arctica Voloshinova

Buccella tenerrima (Bandy)

Cassidulina reniforme Nørvang

Cibicides lobatulus (Walker and Jacob)

Cyclogyra involvens (Reuss)

Dentalina ittai Loeblich and Tappan

Elphidiella arctica (Parker and Jones)

Elphidium albiumbilicatum (Weiss)

Elphidium asklundi Brotzen

Elphidium bartletti Cushman

Elphidium excavatum (Terquem)

Elphidium frigidum Cushman

Elphidium incertum (Williamson)

Elphidium subarcticum Cushman

Elphidium ustulatum Todd

Eoeponidella pulchella (Parker)

Epistominella vitrea Parker

Fissurina cucurbitasena Loeblich and Tappan

Fissurina laevigata Reuss

Fissurina ventricosa (Wiesner)

Gavelinopsis praegeri (Heron-Allen and Earland)

Glandulina laevigata d'Orbigny

Guttulina austriaca d'Orbigny

Guttulina dawsoni Cushman and Ozawa

Guttulina glacialis (Cushman and Ozawa)

Guttulina lactea (Walker and Jacob)

Guttulina yamazaki Cushman and Ozawa

Islandiella helenae Feyling-Hanssen and Buzas

Islandicila inflata (Gudina)

Isl.undiella islandica (Nørvang)

Islandiella norcrossi (Cushman)

Lagena elongata (Ehrenberg)

Lagena semilineata Wright

Lamarckina haliotidea (Heron-Allen and Earland)

Laryngosigma williamsoni (Terquem)

Miliolinella chukchiensis Loeblich and Tappan

Miliolinella subrotunda (Montagu)

Nonion barleeanum (Williamson)

Nonion gudinae (Feyling-Hanssen)

Nonion labradoricum (Dawson)

Nonion orbiculare (Brady)

Oolina acuticosta (Reuss)

Oolina borealis Loeblich and Tappan

Oolina caudigera (Wiesner)

Oolina hexagona (Williamson)

Oolina lineata (Williamson)

Oolina melo d'Orbigny

Oolina williamsoni (Alcock)

Parafissurina rectulostoma Loeblich and Tappan

Patellina corrugata Williamson

Pyrulina cylindroides (Roemer)

Quinqueloculina arctica Cushman

Quinqueloculina borea Gudina

Quinqueloculina longa Gudina

Quinqueloculina seminulum (Linne)

Quinqueloculina stalkeri Loeblich and Tappan

Rosalina vilardeboana d'Orbigny

Rosalina wrightii (Brady)

Scutularis tegminis Loeblich and Tappan

Sigmoidella pacifica Cushman and Ozawa

Sigmomorphina undulosa (Terquem)

Stainforthia loeblichi (Feyling-Hanssen)

Stainforthia schreibersiana (Czjzek)

Triloculina trihedra Loeblich and Tappan

Tritaxis atlantica (F. Parker) 